\title{
Roughing, semi-finishing and finishing of laser surface modified nickel bonded NbC and WC inserts for grey cast iron (GCI) face-milling
}

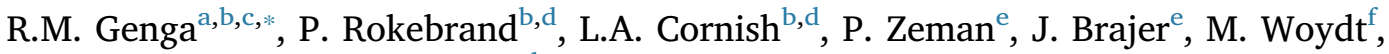 \\ A. Janse van Vuuren ${ }^{g}$, C. Polese ${ }^{\mathrm{b}, \mathrm{c}}$ \\ ${ }^{a}$ Academic Development Unit (ADU), University of the Witwatersrand, South Africa \\ ${ }^{\mathrm{b}}$ DST-NRF Centre of Excellence in Strong Materials, University of the Witwatersrand, South Africa \\ ${ }^{\mathrm{c}}$ School of Mechanical, Industrial and Aeronautical Engineering, University of the Witwatersrand, South Africa \\ ${ }^{\mathrm{d}}$ School of Chemical and Metallurgical Engineering, University of the Witwatersrand, South Africa \\ ${ }^{\mathrm{e}}$ Research Centre of Manufacturing Technology, Czech Technical University in Prague, Czech Republic \\ ${ }^{\mathrm{f}}$ MATRILUB (Materials, Tribology, Lubrication), Germany \\ ${ }^{g}$ CHRTEM, Nelson Mandela University, South Africa
}

\section{A R T I C L E I N F O}

\section{Keywords:}

$\mathrm{NbC}$

$\mathrm{TiC}$

Pulse electric current sintering

Face-milling

Flank wear

\begin{abstract}
A B S T R A C T
An attempt to improve the machining performance of NbC-Ni cutting inserts by rapid pulse electric current sintering (PECS), TiC and $\mathrm{Mo}_{2} \mathrm{C}$ additions and laser surface modification (LSM) was done. Use of a nickel binder and additions $\mathrm{TiC}$ and $\mathrm{Mo}_{2} \mathrm{C}$ to liquid phase sintered (LPS) NbC based samples led to comparable hardness ( $>13 \mathrm{GPa})$ and $\mathrm{K}_{\mathrm{IC}}\left(\sim 10 \mathrm{MPa} \cdot \mathrm{m}^{1 / 2}\right)$ to LPS WC-Co/Ni samples. The laser surface modification (LSM) technique produced $\mathrm{a} \sim 2.5 \mu \mathrm{m}$ thick self-carbide coating, increasing the surface hardness of all the samples. Laser surface modification was done to improve abrasion and attrition wear resistance. Face-milling of grade 17 grey cast iron (BS 1452/GG35) was conducted at 100-500 m/min cutting speeds $\left(v_{\mathrm{c}}\right)$ and $0.25-1.5 \mathrm{~mm}$ depths of cut $\left(\mathrm{a}_{\mathrm{p}}\right)$. The insert wear was measured after every pass, and analyzed by annular dark field scanning transmission electron microscopy (ADF-STEM). During roughing, WC-Co based inserts had the lowest flank wear rate (FWR) values, with the WC-10Co (LPS) insert having a FWR of $10.15 \mu \mathrm{m} / \mathrm{min}$ after $20 \mathrm{~min}$ cutting time. However, during semifinishing and finishing, NbC-4TiC-12Ni (PECS) and NbC-4Mo $\mathrm{C}_{2} \mathrm{C}-4 \mathrm{TiC}-12 \mathrm{Ni}$ (PECS) inserts had the lowest FWR values, showing up to six times longer tool life than the WC-Co (LPS) inserts based inserts and 12 times longer life than the WC-Ni based inserts. Generally, LSM improved the NbC inserts' tool life, reducing the FWR values in all NbC based inserts in all cutting tests.
\end{abstract}

\section{Introduction}

Milling is a machining operation which results in cutting by rotation of the cutting inserts in the opposite direction to of the feed of the workpiece [1]. Face-milling is a type of milling process in which the cutting action is achieved by cutting insert rotation about an axis perpendicular to workpiece [1]. Due to the rotation motion, the inserts undergo a periodic engagement (cutting) and disengagement (cooling) with the workpiece per revolution [1,2]. This results in rapid heating and cooling cycles per revolution, leading to thermal shock at the insert cutting edge [2]. Additionally, depending on the workpiece, the inserts are subjected to abrasion, adhesion, diffusion and mechanical wear $[2,3]$. These factors make face-milling one of the most challenging tribological processes, requiring inserts, such us cemented carbides [3], with good combinations of hardness, strength, toughness and chemical stability at elevated temperatures.

Cemented carbides generally consist of ceramics (tungsten carbide) embedded in a ductile binder matrix (cobalt) [3]. Tungsten carbide (WC) - cobalt (Co) based cemented carbides are the most successful carbides commercially since their conception in 1923 [3], due to the good combination of physical, mechanical and behavioral properties $[2,3]$. However, because of recent supply constraints and increasing cost, as well as poor chemical stability, particularly for machining of steels and cast irons [4], alternatives such as niobium carbide have been investigated [4-6]. Niobium carbide (NbC) has good mechanical and physical properties, such as high hardness ( $\sim 19.6 \mathrm{GPa}[5,6])$, very high melting point $\left(3522^{\circ} \mathrm{C}[4]\right)$ (good for high temperature applications) and low density $\left(7.89 \mathrm{~g} / \mathrm{cm}^{3}\right.$ [6]). Niobium carbide has better high temperature properties than WC, such as retention of hot hardness at elevated temperatures [4] and chemical stability when machining steels

\footnotetext{
* Corresponding author at: Academic Development Unit (ADU), University of the Witwatersrand, South Africa.

E-mail address: rodney.genga@wits.ac.za (R.M. Genga).
} 
and cast irons [3,7]. Generally, NbC-Co cemented carbides produced by conventional liquid phase sintering (LPS) have lower hardnessess and fracture toughnessess than WC-Co cemented carbides, because of excessive NbC grain growth [5,6]. Typically, NbC grains have very high surface energy and low solubility in the $\mathrm{Co}$, $\mathrm{Ni}$ or Fe binders [8], so grain growth is by both coalescence of neighboring grains and Ostwald ripening [2]. Both these mechanisms are thermally activated, giving increased grain size with increased sintering temperature [2]. The excessive NbC grain coarsening occured during the high sintering temperatures and long sintering times during LPS $[2,6]$. The excessive NbC grain coarsening can be prevented by rapid sintering techniques such as pulse electric current sintering (PECS). This technique employs high heating rates and high pressure to consolidate powder compacts to high densities at low temperatures and in short times than conventional LPS $[6,9]$. The lower sintering temperatures and shorter sintering times prevent continuous Ostwald ripening $[3,6,10]$ and coalescence $[2,11]$, reducing the grain growth and increasing the hardness [3]. The hardness of NbC based materials can also be increased by additions of TiC and $\mathrm{Mo}_{2} \mathrm{C}$ grain growth inhibitors [12], and these also improve the high temperature hardness [13], which is important for machining applications $[2,3]$. Cutting tool performance of $\mathrm{NbC}$ can be improved with substitution of Co by Ni, as $\mathrm{Ni}$ higher has better oxidation and thermal cracking resistance, as well as having no phase change from the ductile face centred cubic (fcc) structure [3,14,15].

Grey cast iron (GCI) is a type of cast iron with graphite, which is typically used in applications where high stiffness is more important than tensile strength [16]. Grey cast iron has several attractive properties such as good wear resistance, corrosion resistance, vibration damping and thermal conductivity [16]. These properties and the high stiffness, allow GCI to have several automotive industry applications, including internal combustion engine cylinder blocks, flywheels and clutch plates [16]. Grey cast iron engine blocks and cylinder heads are produced by casting, followed by semi-finishing and finishing machining processes to the final dimensions. This gave the rationale for the attempts here to improve the cutting insert tool life during facemilling of grey cast iron by substitution of WC by NbC, and Co by Ni, $\mathrm{TiC}, \mathrm{Mo}_{2} \mathrm{C}$ additions, as well as PECS processing. The mechanical properties and the wear performance during face-milling of the developed NbC based inserts were compared to WC-Co and WC-Ni based inserts. Additionally, the effects of $\mathrm{Mo}_{2} \mathrm{C}$ and $\mathrm{TiC}$ additions to the NbC$12 \mathrm{Ni}(\mathrm{wt} \%)$ samples were compared to determine which gave the best mechanical properties and machining performance.

\section{Experimental procedure}

\subsection{Starting powders}

The starting powders and their characteristics are given in Table 1. The powder samples were wet milled in $99 \%$ pure ethanol for $24 \mathrm{~h}$ in a steel container with WC milling balls. They were then dried using a rota evaporator at $64^{\circ} \mathrm{C}$ and $80 \mathrm{rpm}$ for $1 \mathrm{~h}$.

Table 1

Starting power specification.

\begin{tabular}{|c|c|c|c|c|}
\hline Materials & $\begin{array}{l}\text { Primary grain } \\
\text { size }(\mu \mathrm{m})\end{array}$ & $\begin{array}{l}\text { Crystal } \\
\text { structure }\end{array}$ & Purity (wt\%) & Source \\
\hline WC & 0.8 & hexagonal & $>99.00$ & $\begin{array}{l}\text { H.C. Starck, } \\
\text { Germany }\end{array}$ \\
\hline Co & 0.9 & hcp & $>99.80$ & OMG Americas, USA \\
\hline $\mathrm{Ni}$ & 3.5 & fcc & $>99.80$ & $\begin{array}{l}\text { Specialty Metals, } \\
\text { South Africa }\end{array}$ \\
\hline $\mathrm{Mo}_{2} \mathrm{C}$ & 1.6 & Cubic & $>99.00$ & Treibacher, Austria \\
\hline $\mathrm{TiC}$ & 1.4 & Cubic & $>99.00$ & Treibacher, Austria \\
\hline $\mathrm{NbC}$ & 0.35 & cubic & $>99.00$ & SECO, Sweden \\
\hline
\end{tabular}

\subsection{Sintering}

The milled composite powders were consolidated in an SPS furnace (HP D5, FCT Systeme, Germany). The powders were poured into cylindrical graphite dies with inner and outer diameters of $20.9 \mathrm{~mm}$ and $40 \mathrm{~mm}$ respectively, and $48 \mathrm{~mm}$ height. The composite powder assemblies were heated in a vacuum $(2 \mathrm{~Pa})$ in two steps, for example WC$10 \mathrm{Co}$ (wt\%) powders were first heated to $1000^{\circ} \mathrm{C}$ at a rate of $200^{\circ} \mathrm{C} /$ min and subsequently to $1240{ }^{\circ} \mathrm{C}$ at a heating rate of $100^{\circ} \mathrm{C} / \mathrm{min}$, and the temperature was held at $1240{ }^{\circ} \mathrm{C}$ for $5 \mathrm{~min}$ during sintering. A cooling rate of $200{ }^{\circ} \mathrm{C} / \mathrm{min}$ was used for all samples. The applied pressure was increased from $16 \mathrm{MPa}$ to $30 \mathrm{MPa}$ at $1000^{\circ} \mathrm{C}$, and from $30 \mathrm{MPa}$ to $50 \mathrm{MPa}$ at $1240{ }^{\circ} \mathrm{C}$ within $30 \mathrm{~s}$. The pressure was then held constant at $50 \mathrm{MPa}$ throughout the rapid sintering cycle. Horizontal and vertical graphite papers were used to separate the powders from the die and punch set-up. Hexagonal boron nitride was placed on the graphite paper to prevent carbon diffusion from the graphite paper to the powders during sintering. The graphite die was wrapped in a carbon cloth to minimize the heat loss from the die surface. The temperature was controlled by an optical pyrometer focused on a central borehole on the upper punch, $1 \mathrm{~mm}$ above the top surface of the sample, to give an accurate measurement of the sample temperature [6]. Consolidation of the composite powder assemblies in the axial direction was monitored by following the position of the plunger.

Liquid phase sintering (HIP, Ultra Temp, USA) was done by heating the compositions in a vacuum $(0.04 \mathrm{MPa})$ at an initial heating rate of $2.4^{\circ} \mathrm{C} / \mathrm{min}$ up to $1200^{\circ} \mathrm{C}$. At $1200^{\circ} \mathrm{C}$, cobalt loss protection (CLP) was carried out by adding argon gas at a pressure of $0.37 \mathrm{MPa}$, and a heating rate $3.5^{\circ} \mathrm{C} / \mathrm{min}$ up to $1430^{\circ} \mathrm{C}$. The temperature was held constant for $75 \mathrm{~min}$, and for the last $20 \mathrm{~min}$, hot isostatic pressing (HIP) was done at 4.4 MPa to eliminate all the surface porosity [3]. The furnace was then water cooled at a rate of $3.5^{\circ} \mathrm{C} / \mathrm{min}$. Different sintering profiles, depending on the powder compositions, were used to achieve good densification (Table 2).

\subsection{Material characterization}

Archimedes' principle was used to determine the density of the sintered samples (ED224S, Sartorius, Germany). Microstructures of the cemented carbides were examined in a field emission scanning electron microscope (SIGMA, Karl Zeiss, Germany), with energy dispersive X-ray spectroscopy (X-act, Oxford Instruments, United Kingdom) and annular dark field scanning transmission electron microscopy (ADF-STEM) (JEOL 2100, with a $\mathrm{LaB}_{6}$ filament, JEOL, Japan). Image analysis was done on SEM micrographs using ImagJ software to attain the mean carbide grain size of the sintered samples. Vickers hardness $\left(\mathrm{HV}_{30}\right)$ was measured on polished specimens after standard metallographic preparation, using a load of $30 \mathrm{~kg}$ (VHT 003 MTA, Vickers Limited, United Kingdom), calculating an average from five indentations at different regions on each sample. The criteria for the accurate derivation of fracture toughness $\left(\mathrm{K}_{1 \mathrm{c}}\right)$ using Shetty's equation [17] were satisfied: $1.25 \leq c / a \leq 2.25$ and $0.25 \leq I / a \leq 2.5$, where $c$ is the crack length from the centre of the indentation to the crack tip, $a$ is half the diagonal of the indentation and $I$ is the difference between $c$ and $a$. The transverse rupture strength (TRS) was determined by the ball-on-three-balls (B3B) method (5500R Universal tester, Instron, USA) on $16 \mathrm{~mm}$ dimeter samples with $1.7 \mathrm{~mm}$ thickness using $13 \mathrm{~mm}$ diameter balls. Loading was achieved using a $50 \mathrm{KN}$ loading cell at a loading speed of $1.5 \mathrm{~mm} /$ min, with a pre-load of $20 \mathrm{~N}$ applied before every test.

\subsection{Laser surface modification}

A Medicom LD50C laser with maximum output power of $50 \mathrm{~W}$ was used for surface modification of the sintered samples and cutting tool inserts. Treatment was done by applying a nano pulse $5 \mathrm{~mJ}$ laser with a process frequency of $5000 \mathrm{~Hz}$. Scanning speed of $100 \mathrm{~mm} / \mathrm{s}$ and laser 
Table 2

Sample compositions and sintering profile.

\begin{tabular}{|c|c|c|c|c|}
\hline \multirow[t]{2}{*}{ Composition (wt\%) } & \multicolumn{2}{|c|}{ Liquid phase sintering profile } & \multicolumn{2}{|c|}{ Pulse electric current sintering profile } \\
\hline & Time (min) & Temperature $\left({ }^{\circ} \mathrm{C}\right)$ & Time (min) & Temperature $\left({ }^{\circ} \mathrm{C}\right)$ \\
\hline WC-10Co (LPS) & 75 & 1430 & & \\
\hline WC-10Co (PECS) & & & 5 & 1240 \\
\hline WC-10Ni (LPS) & 75 & 1430 & & \\
\hline NbC-12Ni (LPS) & 75 & 1430 & & \\
\hline NbC-12Ni (PECS) & & & 5 & 1280 \\
\hline $\mathrm{NbC}-4 \mathrm{Mo}_{2} \mathrm{C}-12 \mathrm{Ni}$ (LPS) & 75 & 1430 & & \\
\hline $\mathrm{NbC}-4 \mathrm{Mo}_{2} \mathrm{C}-12 \mathrm{Ni}$ (PECS) & & & 5 & 1280 \\
\hline NbC-4TiC-12Ni (LPS) & 75 & 1430 & & \\
\hline NbC-4TiC-12Ni (PECS) & & & 5 & 1280 \\
\hline $\mathrm{NbC}-4 \mathrm{Mo}_{2} \mathrm{C}-4 \mathrm{TiC}-12 \mathrm{Ni}$ (LPS) & 75 & 1430 & & \\
\hline $\mathrm{NbC}-4 \mathrm{Mo}_{2} \mathrm{C}-4 \mathrm{TiC}-12 \mathrm{Ni}$ (PECS) & & & 5 & 1280 \\
\hline
\end{tabular}

beam diameter of $100 \mu \mathrm{m}$ were used. An $80 \%$ overlap was applied, and the laser beam was passes four times on every surface.

\subsection{Face-milling}

Cutting tool inserts manufactured from the sintered WC and NbC cemented carbides were secured on to a Pilot F75SN12080 cutting tool holder attached to a Bridgeport GX1000 CNC milling machine with a Oi-MC Fanuc series controller. The Grade 17 grey cast iron (BS 1452/ GG35) workpiece consisted of graphite flakes in a ferritic matrix [18]. The composition of the workpiece is shown in Table 3. The SNMA inserts had a square shape of $12.7 \mathrm{~mm}$ by $12.7 \mathrm{~mm}$ and a thickness of $4.3 \mathrm{~mm}$, with a nose radius of $1.6 \mathrm{~mm}$. Square cutting inserts were manufactured from the cylindrical $20 \mathrm{~mm}$ diameter, $5 \mathrm{~mm}$ height sintered WC and NbC cemented carbides by EDM wire cutting (A422S, CHMER, Taiwan). Chamfering (chamfer angle of $20^{\circ}$ and a chamfer width of $0.2 \mathrm{~mm}$ ) was done on the edges of the square inserts by grinding (40LR, Tacchella, Italy) using a D46 diamond grinding wheel. The workpieces were $150 \times 150 \mathrm{~mm}$ (square) $\times 50 \mathrm{~mm}$ (thick). The machining conditions are shown in Table 4 . The feed of $0.1 \mathrm{~mm} /$ tooth and radial depth of cut of $80 \mathrm{~mm}$ (defined as the diameter of the F75SN12080 cutting tool holder, and also the diameter of the circle traveled by the insert per cut revolution) were held constant for all cutting conditions, and all tests were performed under dry milling conditions (without the use of coolants). Cutting forces in the longitudinal $\left(\mathrm{F}_{\mathrm{x}}\right)$, transverse $\left(\mathrm{F}_{\mathrm{y}}\right)$ and vertical $\left(\mathrm{F}_{\mathrm{z}}\right)$ directions were measured using Kistler force gauge (9366CC0, Kistler multicomponent force link, Switzerland). The Kistler force gauges were attached to the workpiece clamp, and the resultant force (F) was calculated using Eq. (1) [19]:

$\left.\mathrm{F}=\sqrt{\left(\mathrm{F}_{\mathrm{x}}^{2}\right.}+\mathrm{F}_{\mathrm{y}}^{2}+\mathrm{F}_{\mathrm{z}}^{2}\right)$

The average resultant force $\left(F_{R}\right)$ was calculated using Eq. (2):

$\mathrm{F}_{\mathrm{R}}=\left(\sum \mathrm{F}_{\mathrm{i}}\right) / \mathrm{n}$

where $\Sigma \mathrm{F}_{\mathrm{i}}=$ sum of all the resultant forces and $\mathrm{n}=$ total number of resultant forces.

The flank wear and crater wear were evaluated using the same techniques as material characterization. The tool life criterion for failure was $\mathrm{VB}_{\max }$ (maximum length of flank wear) $\geq 0.6 \mathrm{~mm}$, or a shattered cutting edge [20]. Here, flank wear was the length of the wear

Table 3

Chemical compositions of the grey cast iron workpiece.

\begin{tabular}{|c|c|c|c|c|c|c|}
\hline \multirow[t]{2}{*}{ Workpiece } & \multicolumn{6}{|c|}{ Elements (wt\%) } \\
\hline & $\mathrm{C}$ & $\mathrm{Si}$ & Mn & $\mathrm{P}$ & $\mathrm{S}$ & $\mathrm{Fe}$ \\
\hline BS 1452 , grade 17 & 3.4 & 3.0 & 1.2 & 1.2 & 0.15 & Balance \\
\hline
\end{tabular}

scar in the central portion of the active cutting edge [20], and the flank wear rate (FWR) was calculated using Eq. (3) [3]:

$\mathrm{FWR}=\mathrm{VB}_{\max } / \mathrm{t}$

where $\mathrm{t}=$ insert cutting time.

The flank wear was measured after every pass and a maximum cutting time of $20 \mathrm{~min}$ was used for every test. Each test was repeated twice on different cutting edges. Cutting inserts which failed the tool life criterion before $20 \mathrm{~min}$ were removed from the test and their cutting time was recorded. The WC-10Co inserts were used as the standard for wear and tool life.

Any adhered workpiece material was removed from the cutting edges using dilute hydrochloric acid ( $\mathrm{HCl})$ [21-23] before scanning electron microscopy so that the worn surface could be viewed directly.

Before the adhered workpiece material was removed from the cutting edges, cross-sections through the worn regions of the flank were cut using a FIB SEM to reveal the interface between the workpiece and cutting edge. During preparation of the FIB-SEM cross-sections, areas of interested on the worn cutting edges were identified and covered by a carbon-based protective layer. A Gallium (Ga) ion beam of $30 \mathrm{kV}$ energy was used to cut out the cross-sections from the bulk sample, and they were placed on a copper FIB grid. The cross-sections were thinned using a $30 \mathrm{kV} \mathrm{Ga}$ ion beam, first at a high beam current, and then at a slightly lower beam current, until the thinned cross-sections were $\sim 100 \mathrm{~nm}$ thick. The Ga beam energy was reduced to $5 \mathrm{kV}$ and the sample thinned further to $\sim 90 \mathrm{~nm}$. The final preparation involved polishing the sample using a $2 \mathrm{kVGa}$ ion beam. Once all the crosssections from the different inserts were cut out, placed on the copper grip, thinned and polished, they were moved to the annular dark field scanning transmission electron microscope (ADF-STEM) for analysis of the wear on the insert cutting edges.

\section{Results and discussion}

\subsection{Microstructure}

The backscattered SEM images of WC-10Co produced by LPS (Fig. 1(a)) and PECS (Fig. 1(b)) showed smaller carbide grains with poorer binder distribution in the PECS sample (WC-10Co (PECS)). The smaller carbide grains were caused by the lower sintering temperature and shorter dwell time during PECS (Table 2), which prevented continuous Ostwald ripening [6,24]. The better binder pool distribution in the LPS sample (WC-10Co (LPS)) was attributed to the formation of the Co-liquid phase during sintering, which enhanced the WC solubility [3] and the capillarity action of the liquid phase between the pores during the secondary rearrangement stage of sintering [2,25]. However, during PECS, the Co-liquid binder phase only existed momentary, followed by rapid solidification $[9,10]$, which prevented WC solubility and secondary rearrangement, giving poorer binder distribution [10]. 
Table 4

Face-milling parameters.

\begin{tabular}{|c|c|c|c|c|c|}
\hline Test No. & Process & Cutting speed $(\mathrm{m} / \mathrm{min})$ & Depth of cut (mm) & Spindle speed (rpm) & Feed rate $(\mathrm{mm} / \mathrm{min})$ \\
\hline 1 & Roughing & 100 & 1.5 & 400 & 40 \\
\hline 2 & Semi-finishing & 300 & 0.5 & 1200 & 120 \\
\hline 3 & Finishing & 500 & 0.2 & 2000 & 200 \\
\hline
\end{tabular}

The microstructure of WC-10Ni (LPS) (Fig. 2(c)) had larger and poorly distributed Ni-binder pools compared to the WC-10Co (LPS) sample due to of the poorer wetting of WC by Ni than Co $[3,10,26,27]$. The wetting of WC by the liquid phase is defined by the contact angle, $\theta$; smaller contact angles increase the ability of the liquid to spread on the surface [28]. Densification requires a low contact angle to ensure good distribution of the binder phase and agglomeration of grains $[28,29]$. The good wetting of WC by Co is due to the contact angle of $0^{\circ}$ [28], while the poor wetting of WC by $\mathrm{Ni}$ is due to a larger contact angle [3], leading to poor Ni binder distribution and higher WC contiguity [10].

Fig. 2 shows backscattered electron micrographs of NbC-12Ni (LPS), $\mathrm{NbC}-4 \mathrm{Mo}_{2} \mathrm{C}-12 \mathrm{Ni}$, NbC-4TiC-12Ni (LPS) and NbC-4Mo $\mathrm{M}_{2} \mathrm{C}-4 \mathrm{TiC}-12 \mathrm{Ni}$ (LPS) samples. The NbC-12Ni (LPS) sample (Fig. 2(a)) had the larger $\mathrm{NbC}$ grains $(\sim 5.0 \mu \mathrm{m})$ than both LPS WC-10Co $(\sim 1.0 \mu \mathrm{m})$ and WC-10Ni $(\sim 1.0 \mu \mathrm{m})$ samples because of higher drive for grain growth of the ultrafine $(0.35 \mu \mathrm{m}) \mathrm{NbC}$ starting powder (Table 1$)$ than the submicron WC $(0.8 \mu \mathrm{m})[2,11]$, due to higher surface energies [11]. The high surface energies led to grain growth by coalescence $[2,11]$ and Ostwald ripening during the LPS process [2]. Additions of $\mathrm{Mo}_{2} \mathrm{C}$ and $\mathrm{TiC}$ reduced the $\mathrm{NbC}$ grain size (Fig. 2(b) and (c)) due to good grain growth inhibition, with the combined addition of both $\mathrm{Mo}_{2} \mathrm{C}$ and $\mathrm{TiC}$ in the NbC$4 \mathrm{Mo}_{2} \mathrm{C}-4 \mathrm{TiC}-12 \mathrm{Ni}$ (LPS) giving the finest microstructure (Fig. 2(b), (c) and (d)). Molybdenum carbide and titanium carbide were detected by SEM-EDX analysis, and confirmed to be in the NbC grains by annular dark-field (ADF) scanning transmission electron microscopy (STEM) (Fig. 3). Titanium carbide addition to NbC-12Ni (LPS) led to the formation of a Nb-rich core - Ti-rich rim structure (Fig. 3).

Similar to the WC-10Co (wt\%) samples, the PECS NbC samples had reduced $\mathrm{NbC}$ grain size because of the shorter sintering time and lower sintering temperature during PECS, preventing continuous Ostwald ripening $[2,3,6,7]$ and coalescence $[2,11]$. Unlike in the LPS samples, TiC did not fully dissolve in the NbC grain in the NbC-4TiC-12Ni (PECS) and NbC-4Mo $\mathrm{M}_{2} \mathrm{C}-4 \mathrm{TiC}-12 \mathrm{Ni}$ (PECS) samples, resulting in undissolved $\mathrm{TiC}$ (dark phase in Fig. 4). Unlike the LPS samples (Fig. 2(c) and (d)), TiC did not fully dissolve into the NbC grains during PECS (Fig. 4), probably because of the lower sintering temperature (Table 2), because dissolution increases with increased temperature [30]. The partially dissolved TiC inhibited carbide grain growth [2].

\subsection{Mechanical properties}

The Vickers hardnessess and fracture toughnessess $\left(\mathrm{K}_{1 \mathrm{c}}\right)$ of the sintered compositions are shown in Figs. 5 and 6. The PECS samples had higher hardnessess than corresponding samples produced by LPS, with the WC-10Co (PECS) sample having the highest hardness, followed by the $\mathrm{NbC}-4 \mathrm{Mo}_{2} \mathrm{C}-4 \mathrm{TiC}-12 \mathrm{Ni}$ (PECS) sample, and the NbC-12Ni (LPS) sample had the lowest hardness (Fig. 6). The higher hardnessess of PECS samples than their corresponding LPS samples was because of
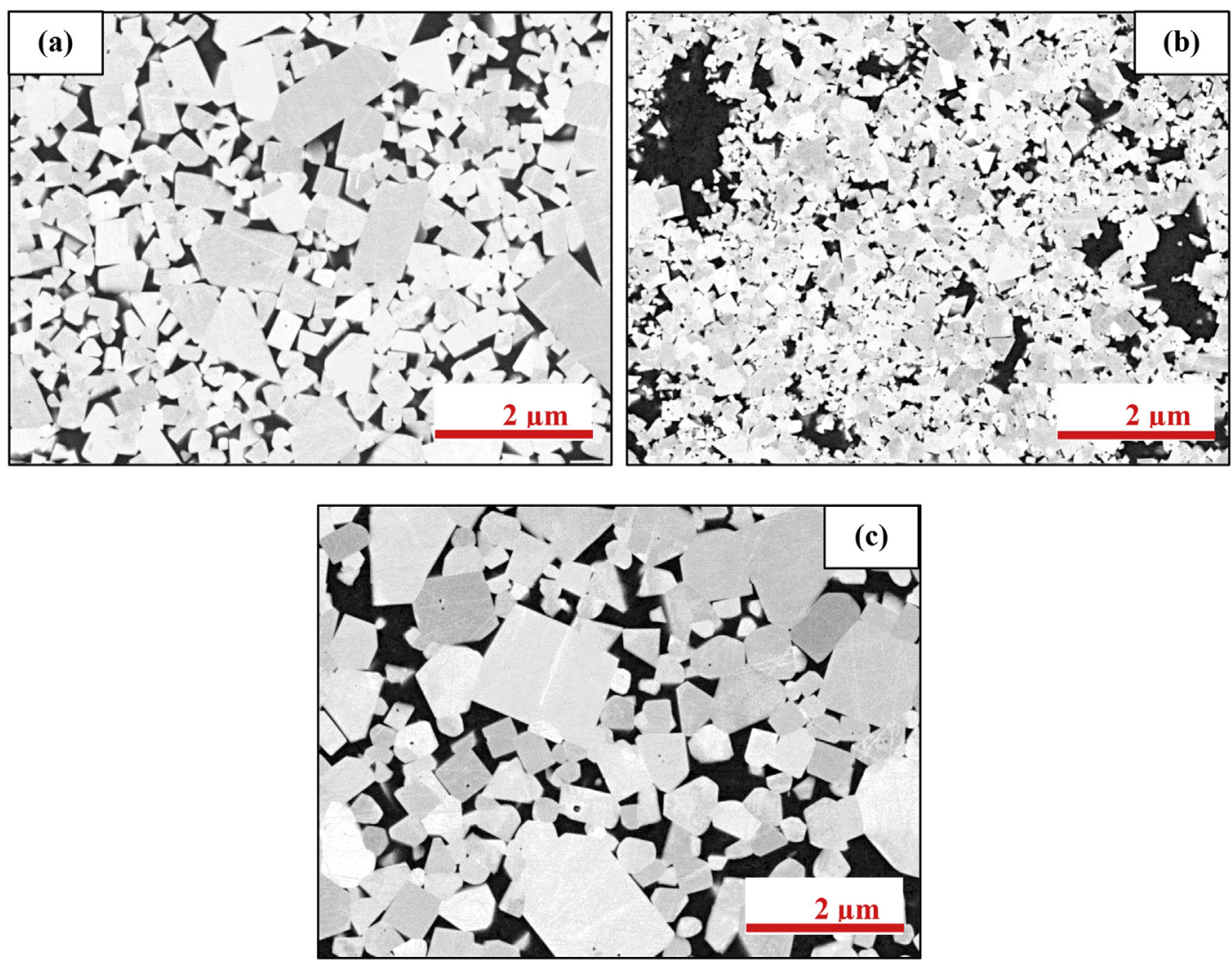

Fig. 1. SEM-BSE images of WC-10Co (wt\%) produced by: (a) LPS and (b) PECS, showing WC (light) and Co (dark), and WC-10Ni (wt\%) produced by: (c) LPS, showing WC (light), Ni (dark). 

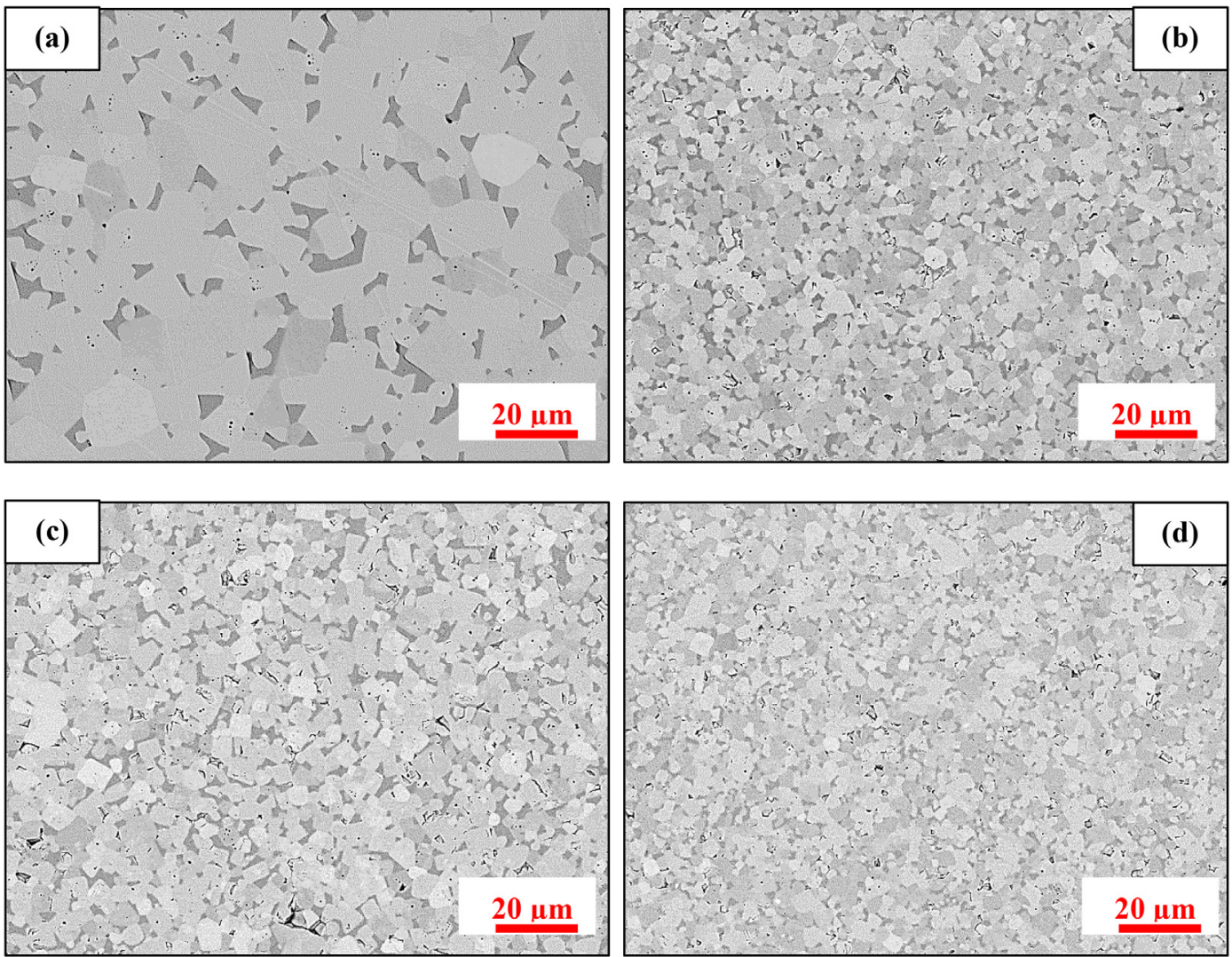

Fig. 2. SEM-BSE images of liquid phase sintered (a) NbC-12Ni (wt $\%$ ), (b) $\mathrm{NbC}-4 \mathrm{Mo}_{2} \mathrm{C}-12 \mathrm{Ni}(\mathrm{wt} \%)$, (c) $\mathrm{NbC}-4 \mathrm{TiC}-12 \mathrm{Ni}(w t \%)$ and (d) $\mathrm{NbC}-4 \mathrm{Mo} \mathrm{C}_{2} \mathrm{C}-4 \mathrm{TiC}-12 \mathrm{Ni}(\mathrm{wt} \%$ ), showing NbC (light) and Ni (dark).

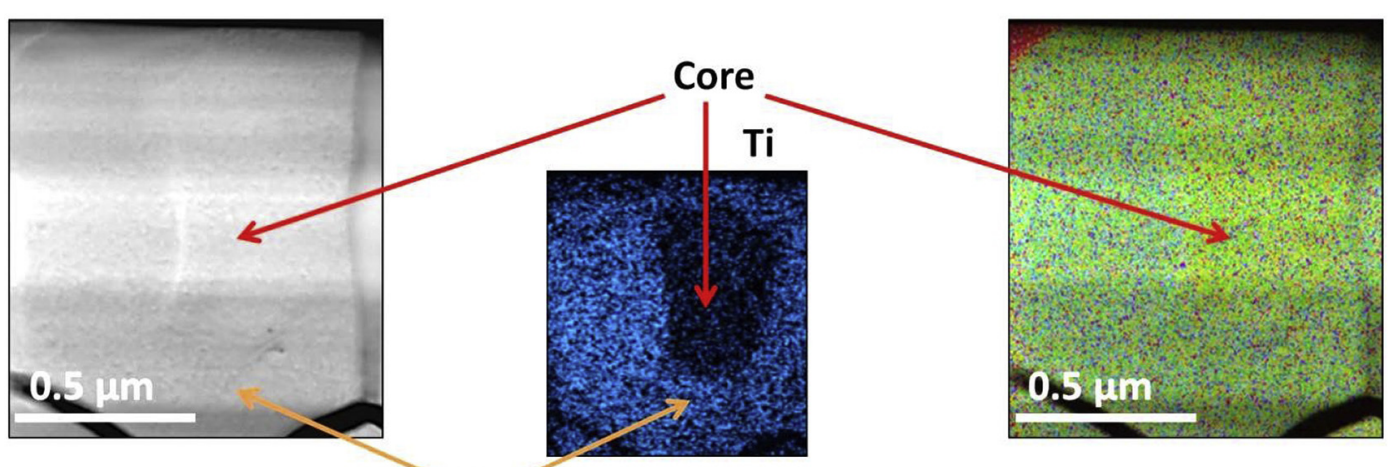

Rim

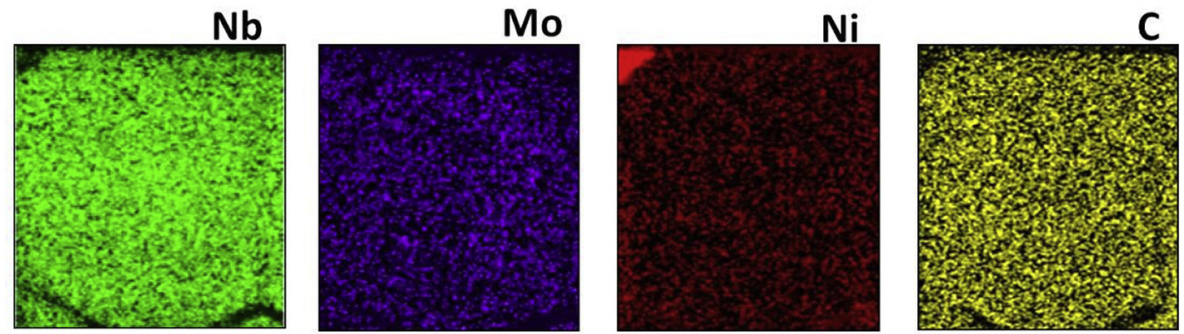

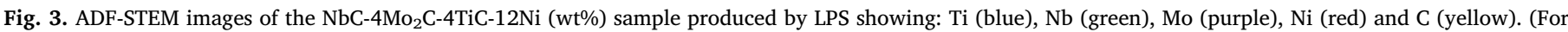
interpretation of the references to colour in this figure legend, the reader is referred to the web version of this article.)

finer mean carbide sizes [2,3,6] (Fig. 5). Although both WC-10Co (wt $\%)$ and WC-10Ni (wt\%) had similar carbide sizes after LPS and PECS, WC-10Co (wt\%) samples had higher hardnessess (Figs. 5 and 6). This was due to the better wetting of WC by Co than Ni, giving better binder distribution $[2,15]$ as well as nickel's higher plasticity than Co
[15,26,27]. Generally, WC-10Co (LPS) had higher hardness than the LPS NbC based samples, and a similar trend was observed in the PECS samples (Fig. 6), because: i) WC (22.5 GPa [6]) has a higher hardness than NbC (19.6 GPa [5]), ii) the good wetting of WC by Co [3], and iii) the NbC samples had a higher binder volume fraction [3]. Huang et al. 


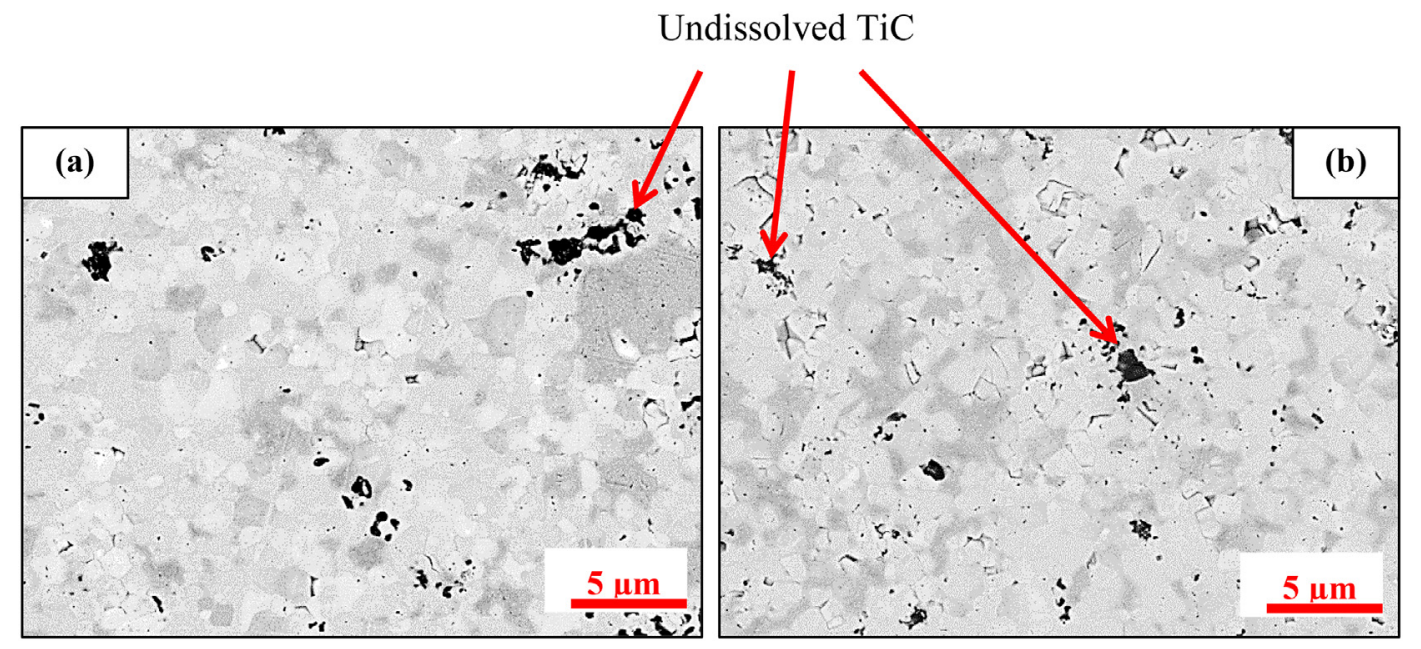

Fig. 4. SEM-BSE images of pulse electric current sintered (a) NbC-4TiC-12Ni (wt\%) and (d) NbC-4Mo ${ }_{2} \mathrm{C}-4 \mathrm{TiC}-12 \mathrm{Ni}$ (wt $\%$ ), showing $\mathrm{NbC}$ (light), Ni (medium) and TiC (dark).

[8] reported good grain growth inhibition by $\mathrm{Mo}_{2} \mathrm{C}$ additions to $\mathrm{NbC}$ cemented carbides, similar to this study (Fig. 2(b)), which gave increased hardness [3]. Generally, reduction in carbide grain size leads to increased hardness and abrasion wear resistance in cemented carbides [3]. Molybdenum carbide addition to NbC-12Ni (LPS) resulted in slightly higher hardness than TiC, due to finer NbC grains (Fig. 5), which also agreed with the smaller grain size with $\mathrm{Mo}_{2} \mathrm{C}$ addition (i.e. better grain growth inhibition than $\mathrm{TiC}$ ). Additions of both $\mathrm{Mo}_{2} \mathrm{C}$ and $\mathrm{TiC}$ to $\mathrm{NbC}-12 \mathrm{Ni}$ (LPS) had even greater carbide growth inhibition effect (Figs. 2 and 5), giving the $\mathrm{NbC}-4 \mathrm{Mo}_{2} \mathrm{C}-4 \mathrm{TiC}-12 \mathrm{Ni}$ (LPS) sample the finest grain size and highest hardness than other LPS NbC samples (Fig. 5). Similar trends of carbide growth inhibition and increased hardness with additions of $\mathrm{Mo}_{2} \mathrm{C}$ and $\mathrm{TiC}$ to $\mathrm{NbC}-12 \mathrm{Ni}$ were observed in the PECS samples (Fig. 5). The higher hardness of the NbC-4TiC-12Ni (PECS) and $\mathrm{NbC}-4 \mathrm{Mo}_{2} \mathrm{C}-4 \mathrm{TiC}-12 \mathrm{Ni}$ (PECS) than $\mathrm{NbC}-12 \mathrm{Ni}$ (PECS) was attributed to carbide growth inhibition and undissolved TiC. As well as inhibiting grain growth, the undissolved $\mathrm{TiC}$ also contributed to increased hardness since TiC has a much higher hardness ( $~ 31 \mathrm{GPa}$ $[31,32])$ than WC and NbC.

To further improve the hardness, abrasion and attrition wear resistance, laser surface modification (LSM) was done on the samples using a nano pulse laser. The LSM technique produced a $\sim 2.5 \mu \mathrm{m}$ thick carbide layer, which increased the surface hardness of all samples (Fig. 7), irrespective of sintering process. Laser surface modification was only done on the WC-10Ni (LPS) sample.

The NbC-12Ni (LPS) sample had the highest $\mathrm{K}_{\mathrm{IC}}$, followed by the NbC-4TiC-12Ni (LPS) and WC-10Co (LPS) samples, while the WC-10Ni (LPS) sample had the lowest $\mathrm{K}_{1 \mathrm{c}}$ of the LPS samples. The higher $\mathrm{K}_{1 \mathrm{c}}$ of NbC-12Ni (LPS) than WC-10Co (LPS) was due to the high binder volume fraction [3,33] and the Ni rather than the Co binder [9]. Nickel has a higher plasticity than Co and never transforms from the ductile fcc structure $[3,15]$. The WC-10Co (LPS) sample had a higher $\mathrm{K}_{1 \mathrm{c}}$ than WC$10 \mathrm{Ni}$ (LPS), due to better wetting of WC by Co than by Ni [3,9], giving more homogenous binder pools [9]. The poor binder distribution in the

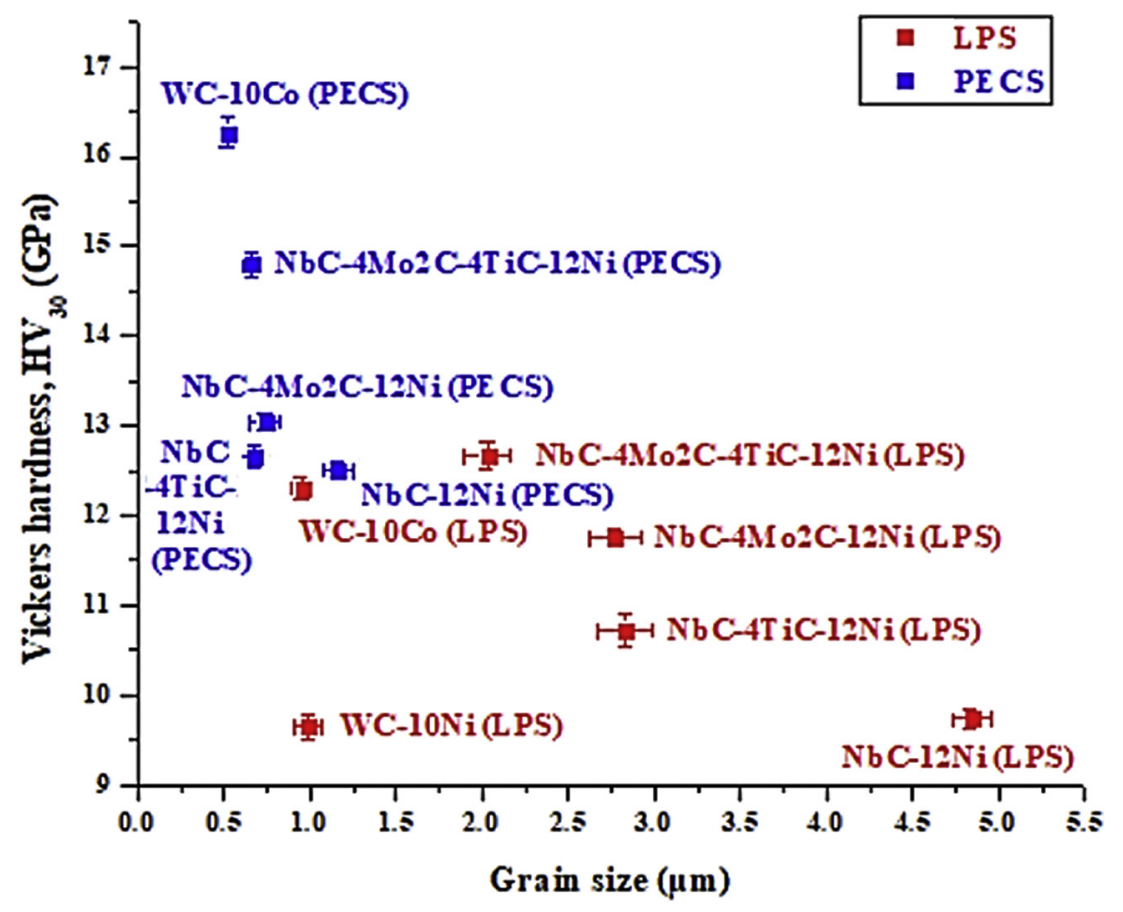

Fig. 5. Effect of sintered carbide grain size on Vickers hardness. 


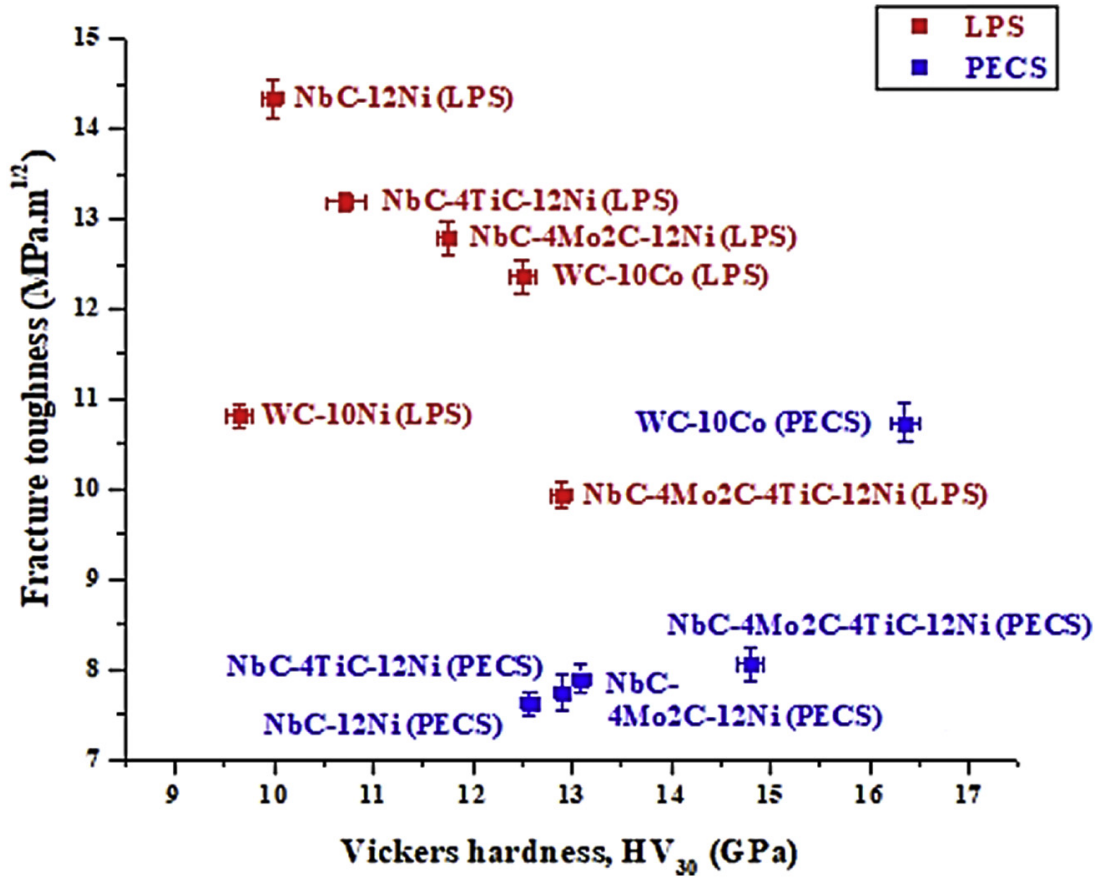

Fig. 6. Effect of Vickers hardness on fracture toughness.

WC-10Ni (LPS) resulted in high contiguity [10], facilitating WC/WC interface fracture, which is the most critical fracture in WC-cemented carbides for crack propagation [34]. Additions of $\mathrm{Mo}_{2} \mathrm{C}$ and TiC to NbC$12 \mathrm{Ni}$ (LPS) increased the hardness, which reduced the $\mathrm{K}_{1 \mathrm{c}}$ [3,6,31]. All LPS samples had higher $K_{1 c}$ than corresponding PECS samples (Fig. 6), due to better binder distribution by the liquid binder phase during LPS, which enhanced carbide solubility [3], as well as the capillarity action of the liquid phase in the pores during the secondary rearrangement stage of sintering [3]. Conversely, in PECS, there was a considerable inhomogeneous temperature distribution from the centre to the surface of the conducting particles (Co and $\mathrm{Ni}$ ), when the pulsed electric current was passed through [9] to the carbides. The temperature at the contacting surface reached several thousand degrees Celsius, and momentarily resulted in local melting, followed by rapid solidification [9,35], which prevented uniform binder distribution [10]. The resulting poor binder distribution increased the carbide contiguity $[3,10]$, facilitating transgranular crack propagation [6,7], which then reduced the fracture toughness. Contiguity is the ratio of carbide/carbide interface area to the total interface area, and hence it is a measure of the degree of contact between carbides in the microstructure [3].

All the PECS samples had lower ball-on-three-balls (B3B) transverse rupture strengths (TRS) than the corresponding LPS samples (Fig. 8), because of the LPS samples' more homogenous microstructures $[3,36]$. The WC based samples had higher TRS than the NbC based samples (Fig. 9), because of the finer and more homogenous microstructures $[3,36]$. Inhomogeneous microstructures with clusters of large carbides or large binder pools (poor binder distribution), reducing TRS [3], because these act as defects in which concentrate stress when stress is applied [3], which leads to failure there even with the average applied stress being below the failure stress of the cemented carbide [3]. The

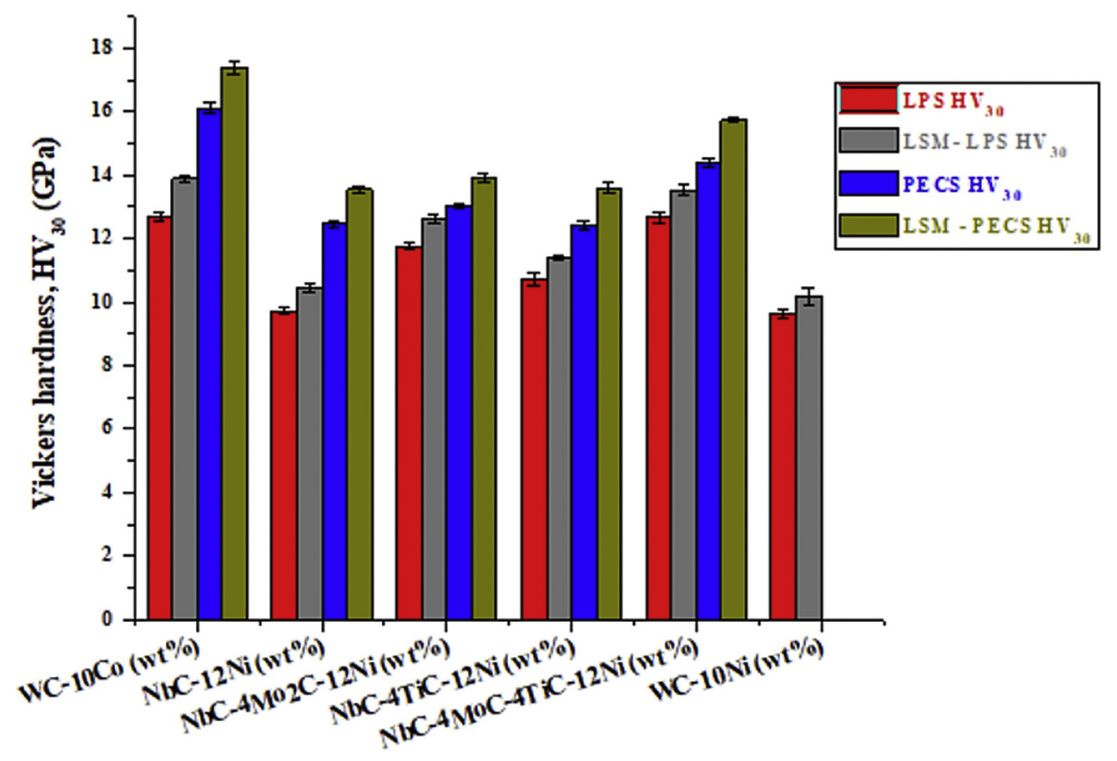

Fig. 7. Effect of laser surface modification (LSM) on Vickers hardness. 


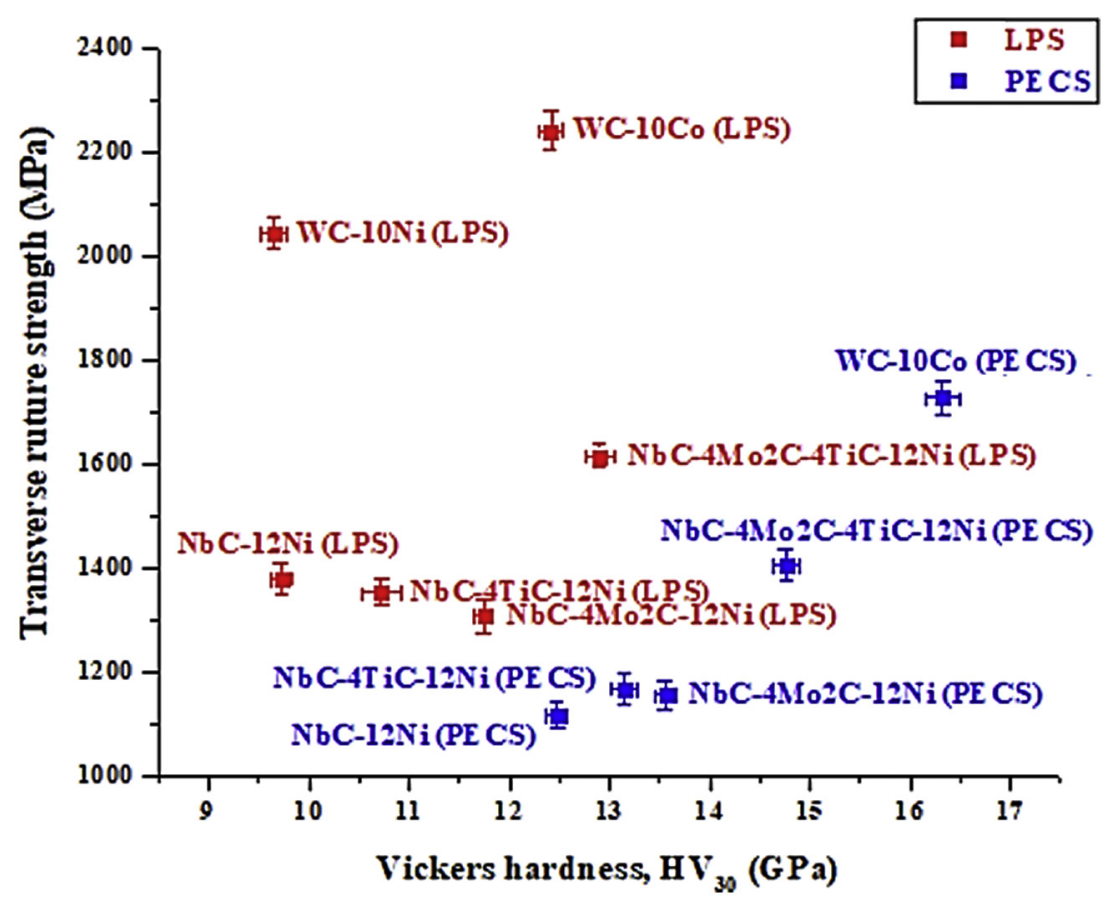

Fig. 8. Effect of Vickers hardness on transverse rupture strength.

additions of $\mathrm{TiC}$ and $\mathrm{Mo}_{2} \mathrm{C}$ to both LPS and PECS NbC-12Ni samples improved the TRS because of the finer microstructure [3,36], with the $\mathrm{NbC}-4 \mathrm{Mo}_{2} \mathrm{C}-4 \mathrm{TiC}-12 \mathrm{Ni}$ (LPS) sample having a high TRS of

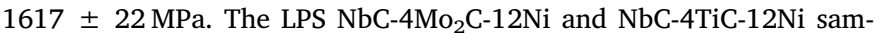
ples had similar B3B TRS values due to the similar microstructures (Fig. 2(b) and (c)), and a similar trend was observed in the PECS samples. Generally, the TRS increased with increase in hardness in the PECS samples (Fig. 8), which was attributed to the finer microstructures $[3,36]$.

\subsection{Face-milling}

The average resultant force $\left(F_{R}\right)$, cutting time $(t)$, maximum flank wear $\left(\mathrm{VB}_{\max }\right)$ and flank wear rate (FWR) of the cutting inserts during face-milling are shown in Table 5. Cutting tool inserts were not manufactured from the LPS $\mathrm{NbC}-12 \mathrm{Ni}, \mathrm{NbC}-4 \mathrm{Mo}_{2} \mathrm{C}-12 \mathrm{Ni}$ and $\mathrm{NbC}-$ 4TiC-12Ni samples, and hence were not used in any of the face-milling tests. During roughing at a cutting speed $\left(v_{\mathrm{c}}\right)$ of $100 \mathrm{~m} / \mathrm{min}$ and a depth of cut $\left(\mathrm{a}_{\mathrm{p}}\right)$ of $1.5 \mathrm{~mm}$, the WC-10Co (LPS) insert had the lowest FWR, with a maximum flank wear $\left(\mathrm{VB}_{\max }\right)$ of $203 \mu \mathrm{m}$ after $20 \mathrm{~min}$, followed by the WC-10Co (PECS) insert (Table 5 and Fig. 9). The WC-10Ni (LPS) insert failed after $6 \mathrm{~min}$, resulting in the highest FWR, followed by the $\mathrm{NbC}-4 \mathrm{Mo}_{2} \mathrm{C}-4 \mathrm{TiC}-12 \mathrm{Ni}$ (LPS) insert that failed after $10 \mathrm{~min}$ (Table 5 and Fig. 9). Generally, cutting insert wear and/or failure had two main causes: chemical wear (diffusion) and mechanical wear (abrasion, attrition and fracture) [37,38]. Flank wear is mainly caused by rubbing at the insert cutting edge/workpiece interface, resulting in abrasive and/ or adhesive wear, as well as chemical wear at high temperatures $[3,37]$. Abrasion is the main flank wear mechanism and is characterized by scratches/grooves in the direction that the insert moves against the

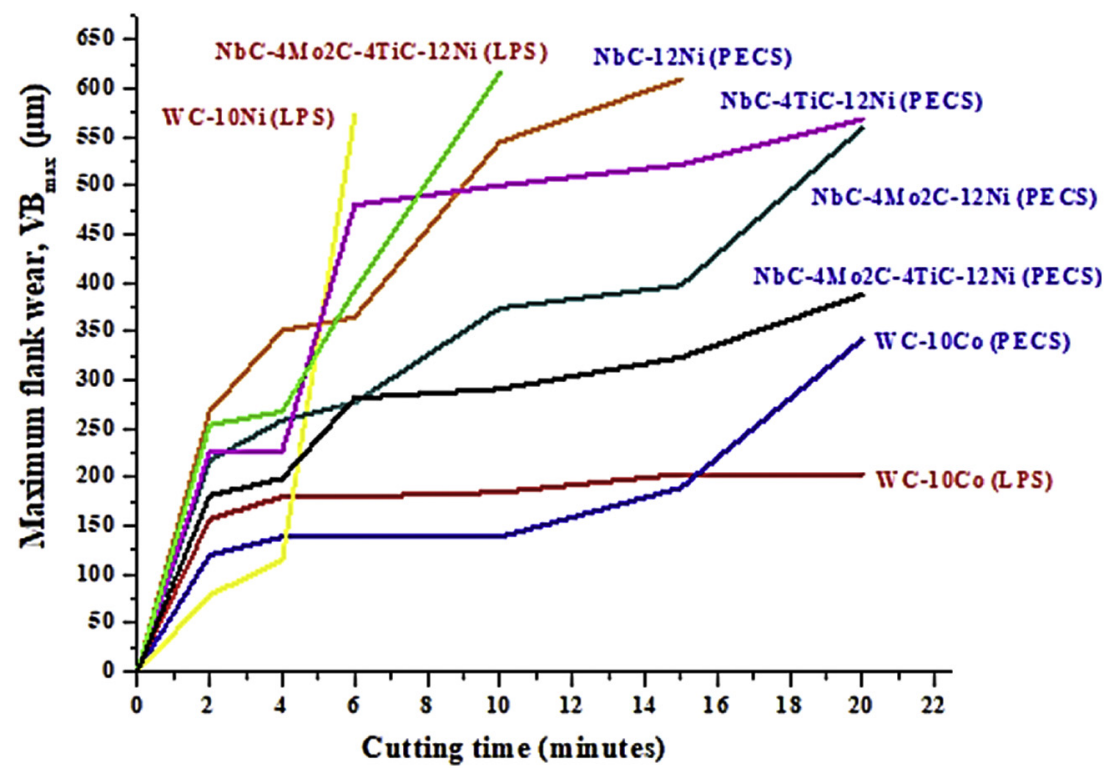

Fig. 9. Variation of maximum flank wear with cutting time during roughing at $v_{\mathrm{c}}=100 \mathrm{~m} / \mathrm{min}$ and $\mathrm{a}_{\mathrm{p}}=1.5 \mathrm{~mm}$. 
Table 5

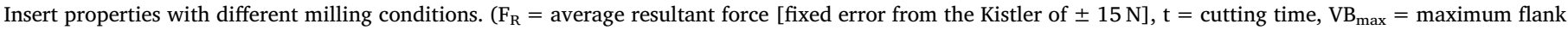
wear, $\mathrm{LSM}=$ Laser surface modification).

\begin{tabular}{|c|c|c|c|c|c|c|c|c|c|}
\hline \multirow[t]{2}{*}{ Milling conditions } & \multirow[t]{2}{*}{ Properties } & \multicolumn{8}{|l|}{ Inserts } \\
\hline & & $\begin{array}{l}\text { WC-10Co } \\
\text { (LPS) }\end{array}$ & $\begin{array}{l}\text { WC-10Co } \\
\text { (PECS) }\end{array}$ & $\begin{array}{l}\text { WC-10Ni } \\
\text { (LPS) }\end{array}$ & $\begin{array}{l}\mathrm{NbC}-12 \mathrm{Ni} \\
(\mathrm{PECS})\end{array}$ & $\begin{array}{l}\mathrm{NbC}-4 \mathrm{Mo}_{2} \mathrm{C}- \\
12 \mathrm{Ni}(\mathrm{PECS})\end{array}$ & $\begin{array}{l}\text { NbC-4TiC- } \\
12 \mathrm{Ni}(\mathrm{PECS})\end{array}$ & $\begin{array}{l}\mathrm{NbC}-4 \mathrm{Mo}_{2} \mathrm{C}- \\
4 \mathrm{TiC}-12 \mathrm{Ni} \\
\text { (LPS) }\end{array}$ & $\begin{array}{l}\mathrm{NbC}-4 \mathrm{Mo}_{2} \mathrm{C}- \\
4 \mathrm{TiC}-12 \mathrm{Ni} \\
\text { (PECS) }\end{array}$ \\
\hline \multirow{4}{*}{$\begin{aligned} v_{\mathrm{c}}= & 100 \mathrm{~m} / \mathrm{min}, \mathrm{a}_{\mathrm{p}}=1.5 \mathrm{~mm} \\
& {[\text { Standard insert }] }\end{aligned}$} & $\mathrm{F}_{\mathrm{R}}(\mathrm{N})$ & 167 & 217 & 260 & 215 & 238 & 192 & 194 & 226 \\
\hline & $\mathrm{t}$ (minutes) & 20 & 20 & 6 & 15 & 20 & 20 & 10 & 20 \\
\hline & $\mathrm{VB}_{\max }(\mu \mathrm{m})$ & 203 & 342 & 592 & 625 & 558 & 568 & 607 & 387 \\
\hline & $\begin{array}{l}\text { FWR }(\mu \mathrm{m} / \\
\min )\end{array}$ & 10.15 & 17.10 & 98.67 & 41.67 & 27.90 & 28.40 & 60.70 & 19.35 \\
\hline \multirow{4}{*}{$\begin{array}{c}v_{\mathrm{c}}=100 \mathrm{~m} / \mathrm{min}, \mathrm{a}_{\mathrm{p}}=1.5 \mathrm{~mm} \\
\quad[\mathrm{LSM} \text { insert }]\end{array}$} & $\mathrm{F}_{\mathrm{R}}(\mathrm{N})$ & 185 & 190 & 450 & 218 & 261 & 188 & 283 & 185 \\
\hline & $\mathrm{t}$ (minutes) & 20 & 20 & 6 & 20 & 20 & 20 & 20 & 20 \\
\hline & $\mathrm{VB}_{\max }(\mu \mathrm{m})$ & 213 & 166 & 658 & 617 & 452 & 517 & 590 & 304 \\
\hline & $\begin{array}{l}\text { FWR }(\mu \mathrm{m} / \\
\min )\end{array}$ & 10.65 & 9.5 & 109.67 & 30.85 & 22.6 & 25.85 & 29.50 & 15.20 \\
\hline \multirow{4}{*}{$\begin{array}{c}v_{\mathrm{c}}=300 \mathrm{~m} / \mathrm{min}, \mathrm{a}_{\mathrm{p}}=0.5 \mathrm{~mm} \\
\quad[\text { Standard insert }]\end{array}$} & $\mathrm{F}_{\mathrm{R}}(\mathrm{N})$ & 385 & 251 & 232 & 212 & 253 & 268 & 331 & 302 \\
\hline & $\mathrm{t}$ (minutes) & 3 & 7.5 & 1.5 & 10.5 & 10.5 & 20 & 3 & 20 \\
\hline & $\mathrm{VB}_{\max }(\mu \mathrm{m})$ & 724 & 563 & Shattered & 591 & 586 & 360 & 717 & 558 \\
\hline & $\begin{array}{l}\text { FWR }(\mu \mathrm{m} / \\
\min )\end{array}$ & 241.33 & 75.07 & - & 56.28 & 55.81 & 18.00 & 239.00 & 27.90 \\
\hline \multirow{4}{*}{$\begin{array}{c}v_{\mathrm{c}}=300 \mathrm{~m} / \mathrm{min}, \mathrm{a}_{\mathrm{p}}=0.5 \mathrm{~mm} \\
\quad[\mathrm{LSM} \text { insert }]\end{array}$} & $\mathrm{F}_{\mathrm{R}}(\mathrm{N})$ & 303 & 176 & 267 & 234 & 204 & 241 & 333 & 142 \\
\hline & $\mathrm{t}$ (minutes) & 3 & 7.5 & 1.5 & 20 & 20 & 20 & 4.5 & 20 \\
\hline & $\mathrm{VB}_{\max }(\mu \mathrm{m})$ & 734 & 602 & Shattered & 447 & 553 & 352 & 596 & 383 \\
\hline & $\begin{array}{l}\text { FWR }(\mu \mathrm{m} / \\
\min )\end{array}$ & 244.33 & 80.26 & - & 22.35 & 27.65 & 17.60 & 132.44 & 19.15 \\
\hline \multirow{4}{*}{$\begin{aligned} v_{\mathrm{c}}= & 500 \mathrm{~m} / \mathrm{min}, \mathrm{a}_{\mathrm{p}}=0.25 \mathrm{~mm} \\
& {[\text { Standard insert }] }\end{aligned}$} & $\mathrm{F}_{\mathrm{R}}(\mathrm{N})$ & 395 & 274 & 265 & 230 & 250 & 156 & 242 & 148 \\
\hline & t (minutes) & 3 & 5 & 2 & 20 & 20 & 20 & 4 & 20 \\
\hline & $\mathrm{VB}_{\max }(\mu \mathrm{m})$ & 634 & 649 & Shattered & 457 & 586 & 383 & 628 & 424 \\
\hline & $\begin{array}{l}\text { FWR }(\mu \mathrm{m} / \\
\min )\end{array}$ & 211.33 & 129.8 & - & 22.85 & 29.30 & 19.15 & 157.00 & 21.20 \\
\hline \multirow{4}{*}{$\begin{array}{c}v_{\mathrm{c}}=500 \mathrm{~m} / \mathrm{min}, \mathrm{a}_{\mathrm{p}}=0.25 \mathrm{~mm} \\
\quad \text { [LSM inert] }\end{array}$} & $\mathrm{F}_{\mathrm{R}}(\mathrm{N})$ & 336 & 270 & 252 & 181 & 207 & 123 & 278 & 150 \\
\hline & $\mathrm{t}$ (minutes) & 3 & 5 & 1 & 20 & 20 & 20 & 5 & 20 \\
\hline & $\mathrm{VB}_{\max }(\mu \mathrm{m})$ & 625 & 697 & Shattered & 402 & 524 & 272 & 692 & 392 \\
\hline & $\begin{array}{l}\text { FWR }(\mu \mathrm{m} / \\
\min )\end{array}$ & 208.33 & 139.40 & - & 20.10 & 26.20 & 13.60 & 138.40 & 19.60 \\
\hline
\end{tabular}

workpiece surface [37]. During machining of grey cast iron, the main wear mechanisms are attrition and abrasion [3,39].

The LPS and PECS WC-10Co inserts had lower FWR values than the $\mathrm{NbC}$ based inserts during roughing, due to their higher TRS and $\mathrm{K}_{1 \mathrm{c}}$ [40] which improved the impact resistance per revolution at the depth of cut of $1.5 \mathrm{~mm}$, preventing mechanical wear by fracturing [2]. Insert failure due to mechanical fracture increases with increased depth of cut, particularly during roughing [41] and is dependent on the TRS [2,3]. Higher TRS and $\mathrm{K}_{1 \mathrm{c}}$ increased the resistance to mechanical fracture [2,3]. The WC-10Co (LPS) insert had a lower FWR than the WC-10Co (PECS) insert, because of the better combination of TRS and $\mathrm{K}_{1 \mathrm{c}}$ (Figs. 7 and 9), whereas PECS samples had poorer binder distribution [9]. Although the WC-10Co (LPS) and WC-10Ni (LPS) inserts were both produced by LPS, the latter had significantly higher FRW because of poorer wetting of WC by Ni than by Co $[3,15]$, giving lower hardness, $\mathrm{K}_{1 \mathrm{c}}$ and TRS [2,3]. Compared to the other NbC inserts, the $\mathrm{NbC}-4 \mathrm{Mo}_{2} \mathrm{C}-4 \mathrm{TiC}-$ $12 \mathrm{Ni}$ (PECS) insert had the lowest FWR because of its better combination of $\mathrm{K}_{1 \mathrm{c}}$ and TRS (Figs. 6 and 8), which improved the mechanical fracture resistance. Transverse rupture strength is a combination of the shear, tensile and compressive strength, and is used as a general measure of the toughness of a cemented carbide [3], while $\mathrm{K}_{\mathrm{Ic}}$ is the resistance to crack propagation once rupture has been initiated. During milling, the insert cutting edges are subjected to shear, tensile and compressive stresses from the cyclic impact with the workpiece per revolution, hence a good combination of TRS and $\mathrm{K}_{\mathrm{Ic}}$ properties is important for prevention of cutting edge fracture [2,42]. Additionally, the $\mathrm{NbC}-4 \mathrm{Mo}_{2} \mathrm{C}-4 \mathrm{TiC}-12 \mathrm{Ni}$ (PECS) insert's lower FWR was also attributed to the fine carbides (Fig. 5), which improved the hardness and abrasion wear resistance [3]. Abrasive wear occurs when hard particles rub against the insert surface, resulting in fragmentation of carbide grains and material removal, forming scratches/groves on the flank face [3].
Higher hardnesses of the cutting edge, usually increases the abrasion resistance [2,3], and the hardness of cemented carbides increases with reduced carbide size [3]. The $\mathrm{NbC}-4 \mathrm{Mo}_{2} \mathrm{C}-12 \mathrm{Ni}$ (PECS) and NbC-4TiC$12 \mathrm{Ni}$ (PECS) inserts had comparable maximum flank wear after $20 \mathrm{~min}$ of machining (Fig. 9) due to similar $\mathrm{K}_{\mathrm{Ic}}$ and TRS (Figs. 6 and 8). During roughing, the laser surface modified inserts had lower FWR values than corresponding inserts without this treatment, with the WC-10Co (PECS) and $\mathrm{NbC}-4 \mathrm{Mo}_{2} \mathrm{C}-4 \mathrm{TiC}-12 \mathrm{Ni}$ (LPS) inserts having the highest reduction in FWR values, $\sim 50 \%$ (Table 5 ), and the latter having increased in cutting time (tool life) from 10 to $20 \mathrm{~min}$ (Fig. 10). The reduced FWR values were due to the increased hardness from LSM (Fig. 7), and increased hardness has been reported to increase abrasion wear resistance $[2,3]$, thus resulting in reduced flank wear.

Crater wear was not observed in any of the inserts (with and without LSM), due to the fine nature of the GCI chips derived from the brittle graphite flakes in the GCI microstructure $[3,41]$, and the formation of fine chips prevented material transport from the rake face.

During semi-finishing at a $v_{\mathrm{c}}=300 \mathrm{~m} / \mathrm{min}$ and $\mathrm{a}_{\mathrm{p}}=0.5 \mathrm{~mm}$, the NbC-4TiC-12Ni (PECS) and NbC-4Mo $\mathrm{M}_{2} \mathrm{C}-4 \mathrm{TiC}-12 \mathrm{Ni}$ (PECS) inserts had the lowest FWR values after a cutting time of $20 \mathrm{~min}$, (Table 5 and Fig. 11), showing up to six times longer tool life than the WC-10Co (LPS) insert and 12 times longer life than the WC-10Ni (LPS) insert. Although the WC-10Co (PECS) insert had better a combination of mechanical properties than the NbC-4TiC-12Ni (PECS) insert, it had higher flank wear (Figs. 11 and 12) after a much shorter machining time. The WC-10Co (PECS) insert had scratches and cavities from carbide pull-out along the worn flank surface (Fig. 12(a) and (b)). The high FWR was attributed to chemical wear from diffusion between the insert and workpiece at the high cutting speed because of iron's higher affinity for carbon than tungsten $[3,7,42]$. The effect of chemical wear was more pronounced during semi-finishing than roughing, because the increased 


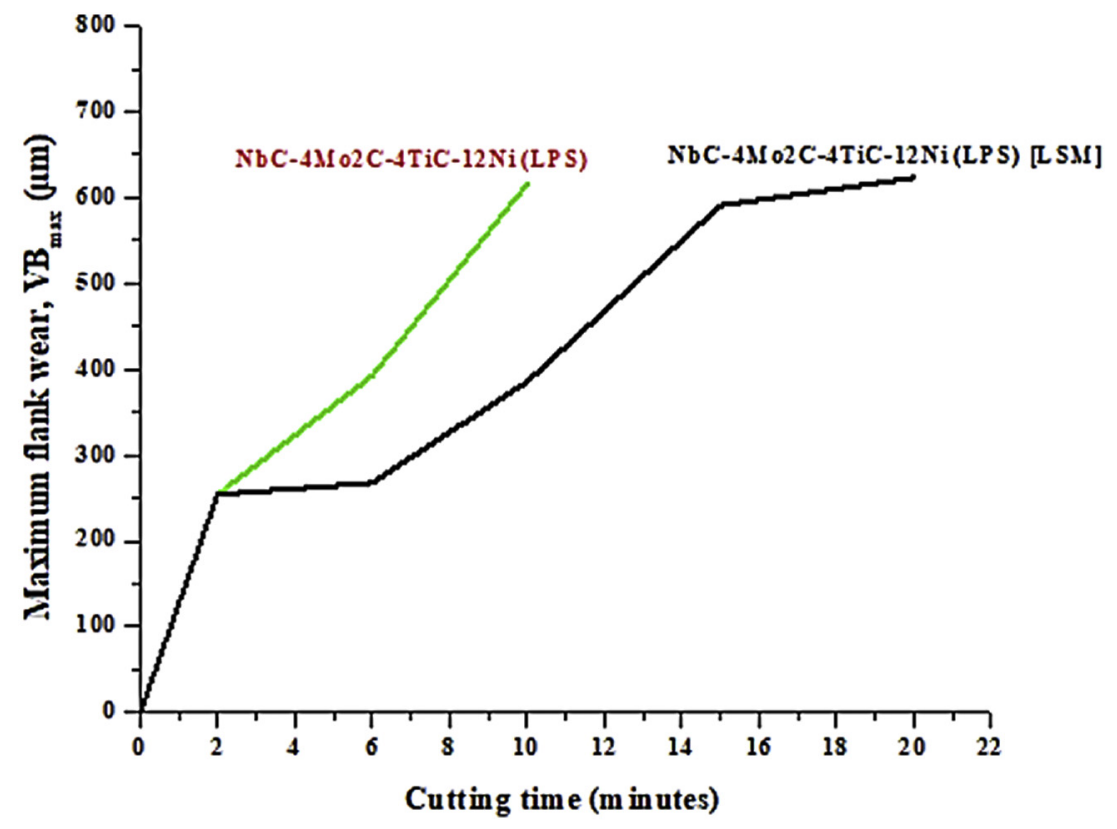

Fig. 10. Effect of LSM on NbC-4Mo 2 C-4TiC-12Ni (LPS) maximum flank wear with cutting time during roughing at $v_{\mathrm{c}}=100 \mathrm{~m} / \mathrm{min}$ and $\mathrm{a}_{\mathrm{p}}=1.5 \mathrm{~mm}$.

cutting speed increased the cutting temperature [2], since diffusion (the main mechanism for chemical wear [3]) is a thermally activated process which increases with increased temperature [30]. An ADF-STEM map of the WC-10Co (PECS) insert cutting edge flank face (Fig. 13) revealed pull-out of carbide grains in the workpiece which exposed the Co binder and allowed slight rounding of the WC grains. The pull-out of carbide grains and exposing of the Co binder was due to attrition wear [7]. During machining of GCI, welding of workpiece material on-to the cutting edge occurred, leading to formation of a build-up edge (BUE) $[3,20,23,41]$. However, due to the continuous motion during machining, the adhered workpiece material broke off from the cutting edge, plucking out carbides with it, forming cavities [3,20]. Smoothing and rounding of carbide grains at the cutting edge/workpiece interface was attributed to chemical wear $[7,41,42]$. The scratches on the worn flank surface (Fig. 12(a) and (b)) were from abrasion by the hard carbide particles adhered to workpiece and surface asperities at the cutting edge/workpiece interface [3,42]. The ADF-STEM mapping image of the NbC-4TiC-12Ni (PECS) insert cutting edge (Fig. 14) revealed a straight interface with slight cracks, demonstrating the good chemical stability of NbC during the machining of cast iron [4,7]. The worn flank surface of the NbC-4TiC-12Ni (PECS) insert (Fig. 12(c) and (d)) had scratches from abrasion wear, cavities from attrition wear and cracks from the mechanical and thermal cyclic loading [2] after the longer cutting time. Although the NbC-12Ni (PECS) and $\mathrm{NbC}-4 \mathrm{Mo}_{2} \mathrm{C}-12 \mathrm{Ni}$ (PECS) inserts had lower FWRs than all the WC based inserts (Table 5), they only lasted half the cutting time (10 min) of both the NbC-4TiC-12Ni (PECS) and $\mathrm{NbC}-4 \mathrm{Mo}_{2} \mathrm{C}-4 \mathrm{TiC}-12 \mathrm{Ni}$ (PECS) inserts (Fig. 11). The lower FWRs in the NbC-4TiC-12Ni (PECS) and $\mathrm{NbC}-4 \mathrm{Mo}_{2} \mathrm{C}-4 \mathrm{TiC}-12 \mathrm{Ni}$ (PECS) inserts than the $\mathrm{NbC}-12 \mathrm{Ni}$ (PECS) and $\mathrm{NbC}-4 \mathrm{Mo}_{2} \mathrm{C}-12 \mathrm{Ni}$ (PECS) inserts were due to the undissolved TiC (Figs. 4 and 14). Since titanium carbide has a much higher hardness [31,32] than NbC [6] and WC [6], it acted as a secondary hardening phase, improving the abrasion wear resistance.

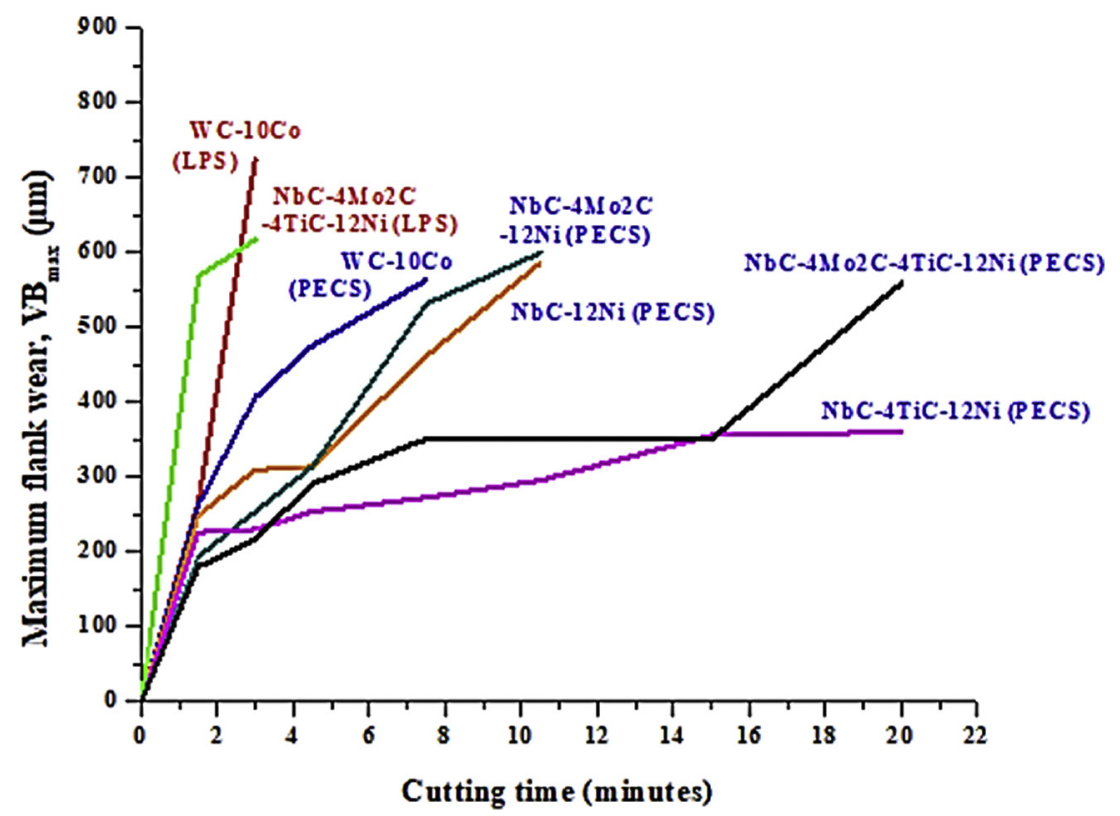

Fig. 11. Variation of maximum flank wear with cutting time during semi-finishing at $v_{\mathrm{c}}=300 \mathrm{~m} / \mathrm{min}$ and $\mathrm{a}_{\mathrm{p}}=0.5 \mathrm{~mm}$. 


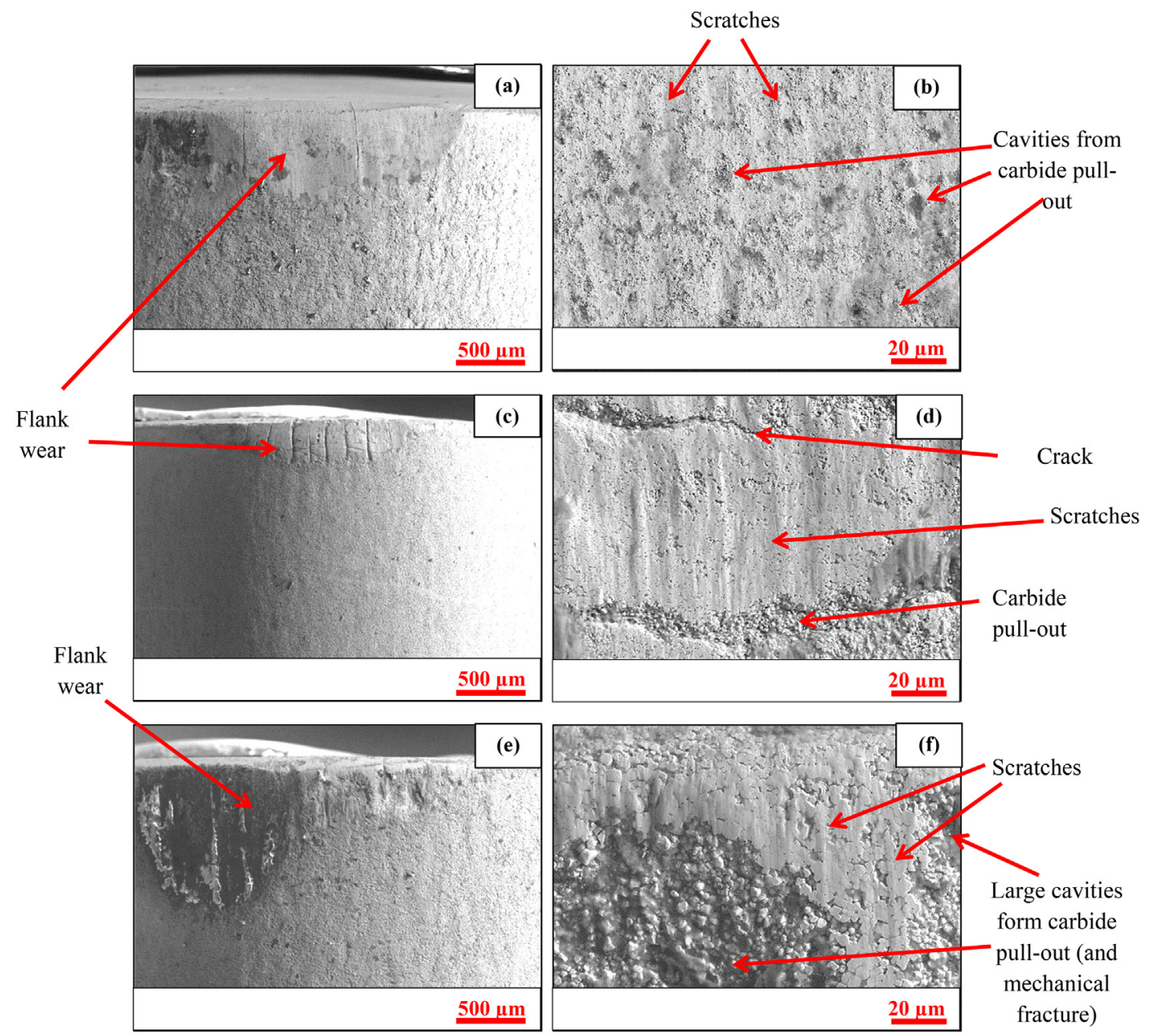

Fig. 12. SEM-SE images of flank wear from milling at $v_{\mathrm{c}}=300 \mathrm{~m} / \mathrm{min}$ and $\mathrm{a}_{\mathrm{p}}=0.5 \mathrm{~mm}$ of: (a) and (b) WC-10Co (PECS) insert after $7.5 \mathrm{~min}$ cutting time, (c) and (d) NbC-4TiC-12Ni (PECS) insert after 20 min cutting time, and (e) and (f) $\mathrm{NbC}-4 \mathrm{Mo}_{2} \mathrm{C}-4 \mathrm{TiC}-12 \mathrm{Ni}$ (PECS) insert after 3 min cutting.

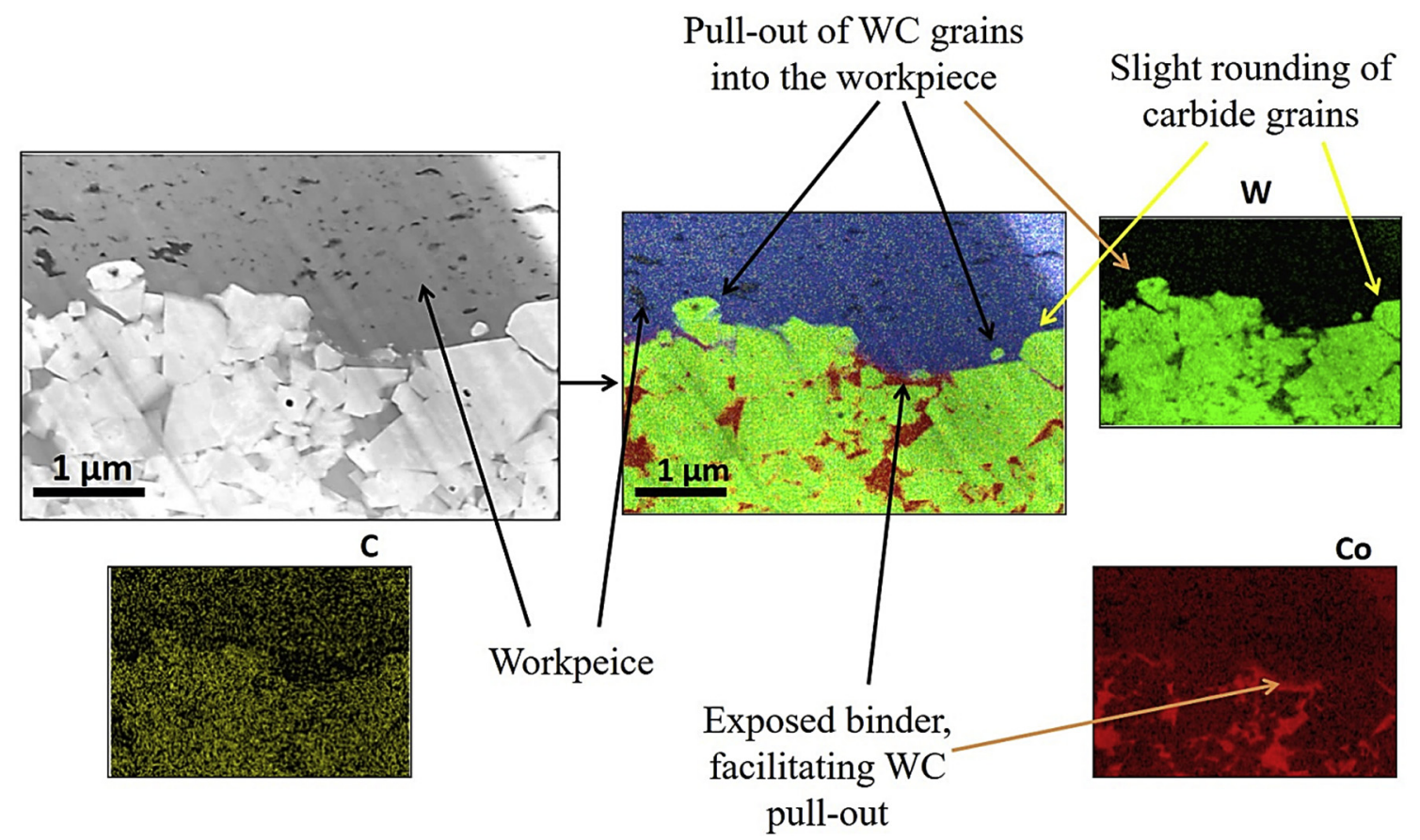

Fig. 13. ADF-STEM mapping images of a cross-section of the WC-10Co (PECS) insert cutting edge/workpiece interface, showing: W (green), Co (red) and C (yellow). (For interpretation of the references to colour in this figure legend, the reader is referred to the web version of this article.) 


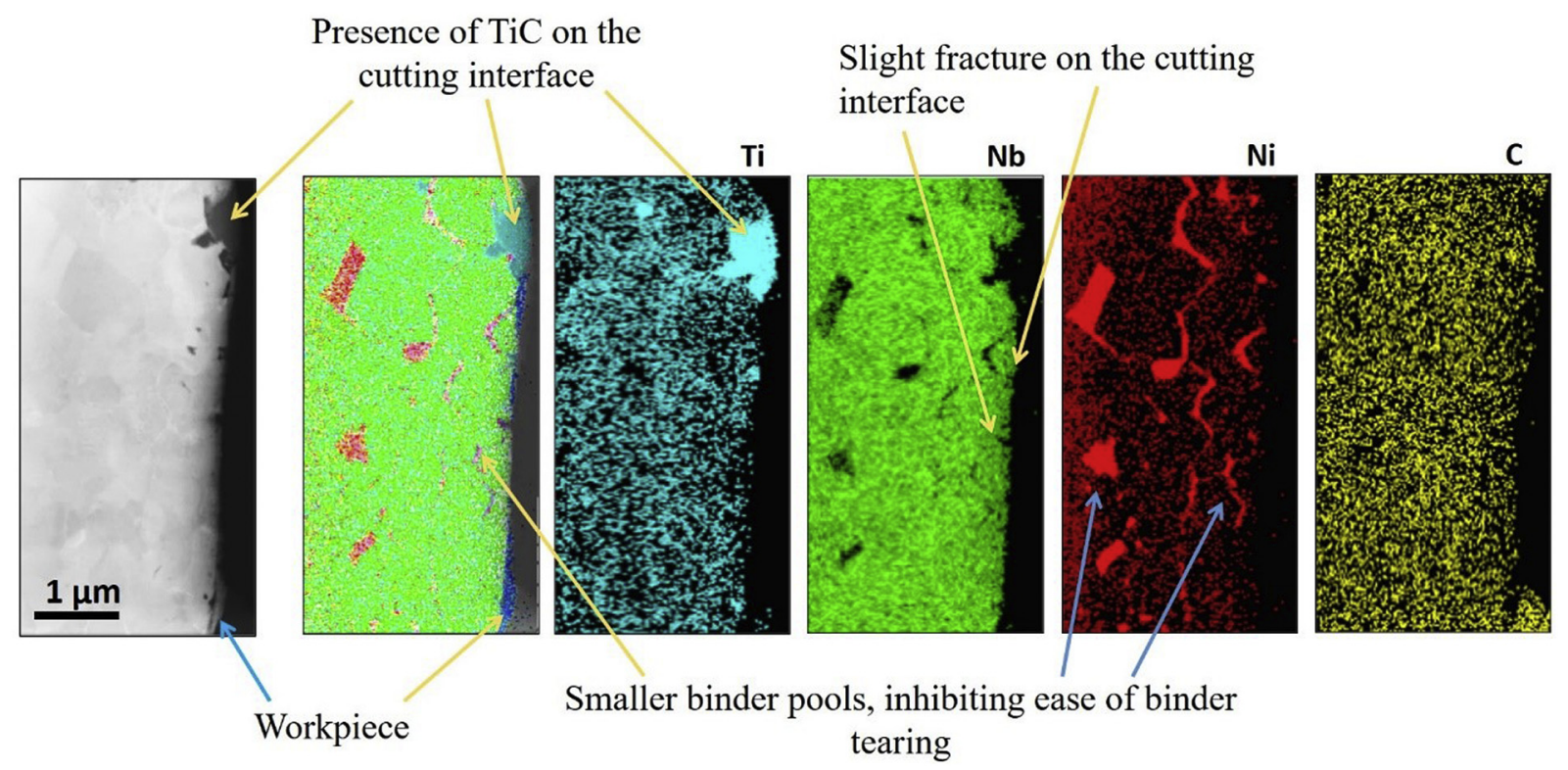

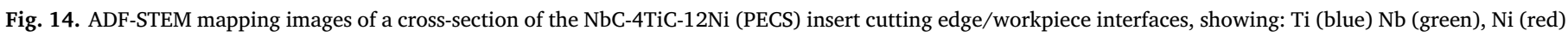
and $\mathrm{C}$ (yellow). (For interpretation of the references to colour in this figure legend, the reader is referred to the web version of this article.)

However, if it had dissolved in the other carbides, even partially, it is likely that there would have been some increase in hardness. Unlike the other PECS NbC based inserts, the NbC-4Mo $\mathrm{M}_{2} \mathrm{C}-4 \mathrm{TiC}-12 \mathrm{Ni}$ (LPS) insert failed after $4 \mathrm{~min}$ of cutting, due to its larger mean carbide sizes [2] (Fig. 5). The worn flank surface of the $\mathrm{NbC}-4 \mathrm{Mo}_{2} \mathrm{C}-4 \mathrm{TiC}-12 \mathrm{Ni}$ (LPS) insert had large cavities from carbide pull-out due to attrition wear $[3,7]$. Attrition wear rate is higher in cemented carbides with large carbide grains, due to ease of pull-out of large grains than smaller grains $[3,7]$. During semi-finishing, LSM reduced the FWR values in the NbC inserts, because of the improved abrasion wear resistance due to the increased surface hardness. Although LSM improved the surface mechanical properties, it had negligible effect on the WC based inserts FWR values, because of the chemical wear which still took place, due to iron's higher affinity for carbon than WC [3].

Similarly, during finishing at a $v_{\mathrm{c}}=500 \mathrm{~m} / \mathrm{min}$ and $\mathrm{a}_{\mathrm{p}}=0.25 \mathrm{~mm}$, both NbC-4TiC-12Ni (PECS) and NbC-4Mo $2 \mathrm{C}-4 \mathrm{TiC}-12 \mathrm{Ni}$ (PECS) inserts had the lowest flank wear (Table 5 and Fig. 15), with the later having the lowest FWR after a cutting time of $20 \mathrm{~min}$. Although the NbC$4 \mathrm{Mo}_{2} \mathrm{C}-12 \mathrm{Ni}$ (PECS) insert had a slightly higher hardness than the NbC-
4TiC-12Ni (PECS) insert, the presence of undissolved TiC in the latter improved the abrasion wear resistance, giving lower FWR during finishing (Table 5). Apart from the $\mathrm{NbC}-4 \mathrm{Mo}_{2} \mathrm{C}-4 \mathrm{TiC}-12 \mathrm{Ni}$ (LPS) insert, all the NbC based inserts had much lower flank wear values after longer cutting times than the LPS and PECS WC-10Co inserts (Table 5 and Fig. 15). Similar to semi-finishing, the higher FWR values in the WC$10 \mathrm{Co}$ inserts were due to poorer chemical wear resistance than the $\mathrm{NbC}$ based inserts, because of iron's higher affinity for carbon than WC [3]. The NbC inserts, the $\mathrm{NbC}-4 \mathrm{Mo}_{2} \mathrm{C}-4 \mathrm{TiC}-12 \mathrm{Ni}$ (PECS) insert had the lowest FWR of the $\mathrm{NbC}$ inserts, due to its higher hardness from the finer carbide microstructure, which improved the abrasion resistance [2,3], reducing flank wear from abrasion. Conversely, the high FWR for the $\mathrm{NbC}-4 \mathrm{Mo}_{2} \mathrm{C}-4 \mathrm{TiC}-12 \mathrm{Ni}$ (LPS) insert was attributed to the larger carbides which reduced hardness [3], resulting in reduced resistance to hard abrasive particles (abrasion), as well as facilitating ease of pull-out of carbides (attrition) during milling [2,7]. Similar to semi-finishing, LSM reduced the FWR in all the NbC inserts and had negligible effect on the WC-10Co based inserts (Table 5) because diffusion between cutting edge and workpiece occurred due to iron's higher affinity for carbon

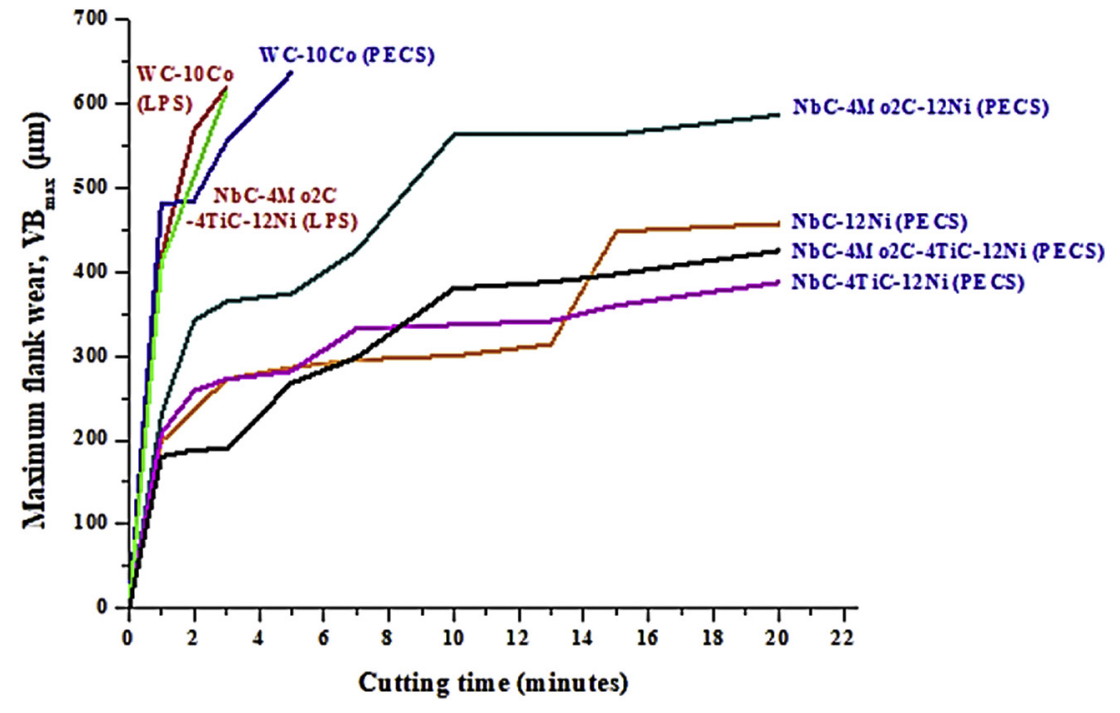

Fig. 15. Variation of maximum flank wear with time during finishing at $v_{\mathrm{c}}=500 \mathrm{~m} / \mathrm{min}$ and $\mathrm{a}_{\mathrm{p}}=0.25 \mathrm{~mm}$. 
than WC [3]. The reduced FWR values in the NbC inserts was attributed to the increased surface hardness and abrasion wear resistance. The WC-10Ni (LPS) insert cutting edges shattered during semi-finishing and finishing, due to the poor hardness and $\mathrm{K}_{\mathrm{Ic}}$ (Fig. 6), reducing the abrasion [3] and mechanical fracture resistance [2], as well as poor chemical wear resistance due to iron's higher affinity for carbon than WC [3]. Overall, the WC-10Co based inserts performed better during roughing, but the $\mathrm{NbC}-4 \mathrm{TiC}-12 \mathrm{Ni}$ (PECS) and $\mathrm{NbC}-4 \mathrm{Mo}_{2} \mathrm{C}-4 \mathrm{TiC}-12 \mathrm{Ni}$ (PECS) inserts performed better during semi-finishing and finishing.

\section{Conclusions}

Pulse electric current sintering (PECS) resulted in higher hardness and lower fracture toughness $\left(\mathrm{K}_{1 \mathrm{c}}\right)$ than liquid phase sintering (LPS). The WC-10Co (LPS) and WC-10Co (PECS) samples had the best combination of hardness, $\mathrm{K}_{1 \mathrm{c}}$ and ball-on-three-balls (B3B) transverse rupture strength (TRS) compared to the NbC based samples, although additions of $\mathrm{TiC}$ and $\mathrm{Mo}_{2} \mathrm{C}$ improved these properties. Addition of $\mathrm{Mo}_{2} \mathrm{C}$ to $\mathrm{NbC}-12 \mathrm{Ni}$ (LPS) gave slightly better carbide growth inhibition than TiC, with slightly higher hardness. Laser surface modification improved the hardness of the samples. During roughing, the WC-10Co (LPS) and WC10Co (PECS) inserts had the lowest FWR after a cutting time of $20 \mathrm{~min}$, due to the high TRS and $\mathrm{K}_{1 \mathrm{c}}$. However, during semi-finishing and finishing, the NbC-4TiC-12Ni (PECS) and NbC-4Mo $\mathrm{M}_{2} \mathrm{C}-4 \mathrm{TiC}-12 \mathrm{Ni}$ (PECS) inserts had the lowest FWR values after a cutting time of $20 \mathrm{~min}$, showing up to six times longer cutting time than the WC-10Co (LPS) insert. Although the $\mathrm{NbC}-4 \mathrm{Mo}_{2} \mathrm{C}-12 \mathrm{Ni}$ (PECS) insert had comparable hardness, $\mathrm{K}_{\mathrm{Ic}}$ and $\mathrm{B} 3 \mathrm{~B}$ TRS to the NbC-4TiC-12Ni (PECS) insert, the latter had lower FWRs during semi-finishing and finishing because of the presence of undissolved TiC which improved the abrasion wear resistance. The WC based inserts had lower FWR values than most of the NbC based inserts, due to WC's poorer chemical stability than NbC during machining of Fe alloys. The good machining performance of the $\mathrm{NbC}-4 \mathrm{TiC}-12 \mathrm{Ni}$ (PECS) and $\mathrm{NbC}-4 \mathrm{Mo}_{2} \mathrm{C}-4 \mathrm{TiC}-12 \mathrm{Ni}$ (PECS) inserts was due to the good combinations of hardness, chemical stability and attrition wear resistance, as well as the presence of undissolved TiC. Generally, laser surface modification (LSM) reduced the FWR values for most of the inserts during roughing, and for all the NbC based inserts during semi-finishing and finishing, due to improved abrasion wear resistance. Although LSM improved the surface hardness, the poor chemical stability of the WC-10Co based inserts during semi-finishing and finishing gave high FWR values. The WC-10Ni (LPS) insert had the highest FWR during roughing and shattered during semi-finishing and finishing due to its poorer hardness and $\mathrm{K}_{\mathrm{IC}}$.

\section{Acknowledgements}

This work was financially supported by Department of Science and Technology and the National Research Foundation, South Africa. The authors are grateful to Dr. Chris Freemantle and Mr. Joseph Oupa Mukwevho from Pilot Tools (Pty) Ltd. for provision of powders and liquid phase sintering facilities, Ms. Tasneem Chamda and Mr. Marco Fanuel Cossa are thanked for assistance with the machining and lab work, Mr. Ndivhuwo Nelwalani for the SEM images, as well as Mr. Gerrard Peters for discussions and advice. The authors are also grateful to Companhia Brasileira de Metallurgia e Mineração (CBMM), São Paulo, Brazil, for supplying the NbC powder. Finally, I would like thank God for making this possible.

\section{References}

[1] T. Childs, K. Maekawa, T. Obikawa, Y. Yamane, Metal Machining - Theory and Application, Wiley \& Sons Inc, New York, USA, 2000.

[2] R.M. Genga, G. Akdogan, C. Polese, J.C. Garrett, L.A. Cornish, Abrasion wear, thermal shock and impact resistance of WC-cemented carbides produced by PECS and LPS, Int. J. Refract. Met. Hard Mater. 29 (2015) 133-142.

[3] G.S. Upahyaya, Cemented Tungsten Carbide Production, Properties and Testing,
Noyes Publications, New Jersey, USA, 1998.

[4] M. Woydt, H. Mohrbacher, The use of niobium carbide (NbC) as cutting tools and for wear resistance tribosystems, Int. J. Refract. Met. Hard Mater. 49 (2015) $212-218$.

[5] S.G. Huang, O. Van der Biest, J. Vleugles, VC doped WC-NbC-Co hardmetals, Mater Sci. Eng. 488 (2008) 420-427.

[6] S.G. Huang, R.L. Liu, L. Li, O. Van der Biest, J. Vleugels, NbC as a grain growth inhibitor and carbide in WC-Co hardmetals, Int. J. Refract. Met. Hard Mater. 26 (2008) 389-395.

[7] R.M. Genga, L.A. Cornish, M. Woydt, A. Janse van Vuuren, C. Polese, Microstructure, mechanical and machining properties of LPS and SPS NbC cemented carbides for face-milling of grey cast iron, Int. J. Refract. Met. Hard Mater. 73 (2018) 111-120.

[8] S.G. Huang, J. Vleugels, H. Mohrbacher, M. Woydt, Microstructure and tribological performance of NbC-Ni cermets modified by VC and $\mathrm{Mo}_{2} \mathrm{C}$, Int. J. Refract. Met. Hard Mater. 66 (2017) 188-197.

[9] M. Tokita, Mechanism of Spark Plasma Sintering, Kawasaki-Shi, Kanagawa, Japan, Sumitomo Coal Mining Company, Ltd, 1999.

[10] R.M. Genga, L.A. Cornish, G. Akdogan, Effect of $\mathrm{Mo}_{2} \mathrm{C}$ addition on the properties of SPS manufactured WC-TiC-Ni cemented carbide, Int. J. Refract. Met. Hard Mater. 41 (2013) 12-21.

[11] X. Wang, Z.Z. Fang, H.Y. Sohn, Grain growth during the early stage sintering of nanosized WC-Co powders, Int. J. Refract. Met. Hard Mater. 26 (2008) 232-242.

[12] S.G. Huang, J. Vleugels, H. Mohrbacher, M. Woydt, Microstructure and mechanical properties of $\mathrm{NbC}$ matrix cermets using Ni containing metal binder, Metal Powder Rep. 71 (5) (2016) 349-355.

[13] V.K. Sarin, L. Llanes, D. Mari, Comprehensive Hard Materials, Elsevier, Oxford, UK, 2014.

[14] K. Bonny, P. De Beast, J. Vleugles, S. Haung, B. Lauwers, Dry reciprocating sliding friction and wear response of WC-Ni cemented carbides, Tribol. Lett. 31 (2008) (199-109).

[15] T.W. Penrice, Alternative binders for hard metals, J. Mater. Shaping Technol. 5 (1987) 35-39.

[16] M. Genç, C. İmer, Graphite flake size effects to thermal durability of automobile flywheel under forced slippage, 3rd World Congress on Mechanical, Chemical, and Material Engineering, 2017, pp. 1-8 ICMIE121.

[17] D.K. Shetty, I.G. Wright, P.N. Mincer, A.H. Clauer, Indentation fracture of WC-Co cermets, J. Mater. Sci. 20 (1985) 1873-1882.

[18] ASTM A247-67, Standard Test Method for Evaluating the Microstructure of Graphite in Iron Castings, (1998).

[19] E. Kuram, Nose radius and cutting speed effects during milling of AISI 304 material, Mater. Manuf. Process. 32 (2) (2017) 185-192.

[20] G. Boothryd, W.A. Knight, Fundamentals of Machining and Machine Tools, 3rd ed., Taylor \& Francis Group, Florida, USA, 2006.

[21] H. Xiao, Wear behavior and wear mechanism of ceramic tools in machining steel hardened alloy, Wear 139 (1990) 439-451.

[22] G.K.L. Goh, L.C. Lim, M. Rahman, S.C. Lim, Effect of grain size on wear behavior of alumina cutting tools, Wear 206 (1997) 24-32.

[23] P.A. Dearnley, Introduction to Surface Engineering, Cambridge University Press, Cambridge, UK, 2017.

[24] H. Rong, Z. Peng, X. Ren, Y. Peng, C. Wang, Z. Fu, L. Qi, H. Miao, Ultrafine WC-Ni cemented carbides fabricated by spark plasma sintering, Mater. Sci. Eng. A 532 (2011) 543-547.

[25] I. Jenkins, J.V. Woods, Powders Metallurgy-An Overview, The Intitute of Metals, Brookfield, USA, 1991.

[26] Z. Guo, J. Xiong, M. Yang, C. Jiang, WC-TiC-Ni cemented carbide with enhanced properties, J. Alloys Compd. 465 (2008) 157-162.

[27] Z. Guo, J. Xiong, M. Yang, X. Song, C. Jiang, Effect of $\mathrm{Mo}_{2} \mathrm{C}$ on the microstructure and properties of WC-TiC-Ni cemented carbides, Int. J. Refract. Met. Hard Mater. 26 (2008) 601-605.

[28] N.M. Parikh, M. Humenik, Wettability and microstructure studies in liquid phase sintering, J. Am. Ceram. Soc. 40 (1956) 315-320.

[29] R.M. German, P. Suri, S.J. Park, Liquid phase sintering, J. Mater. Sci. 44 (2009) $1-39$.

[30] D.R. Askeland, P.P. Fulay, Essentials of Material Science and Engineering, Second ed., Cengage Learning, Stanford, UK, 2010.

[31] K.J.A. Brookes, Hardmetals and Other Hard Materials, International Carbide Data, Hertfordshire, UK, 1975.

[32] H.C. Kim, D.K. Kim, I.J. Shon, Sintering behavior and mechanical properties of binderless WC-TiC produced by pulse current activated sintering, J. Ceram. Process. Res. 8 (2) (2007) 91-97.

[33] J.L. Chermant, F. Osterstock, Fracture toughness and toughness of WC-Co composites, J. Mater. Sci. 11 (1976) 1939-1951.

[34] R.M. Genga, L.A. Cornish, M. Woydt, A. Janse van Vuuren, C. Polese, Microstructure, mechanical and machining properties of LPS and SPS NbC cemented carbides for face-milling of grey cast iron, Int. J. Refract. Met. Hard Mater. 73 (2018) 111-120.

[35] X. Song, X. Liu, J. Zhang, Neck formation and self adjusting mechanism of neck growth of conducting in spark plasma sintering, J. Am. Ceram. Soc. 89 (2) (2006) 494-500.

[36] S. Sheikh, R. M'Saoubi, P. Flasar, M. Schwinda, T. Persson, J. Yang, L. Llanes, Fracture toughness of cemented carbides: testing method and microstructural effects, Int. J. Refract. Met. Hard Mater. 49 (2015) 153-160.

[37] S.A. Kumar, A.R. Durai, T. Sornakumar, The effect of tool wear on tool life of alumina-based ceramic cutting tools while machining hardened martensitic stainless steel, J. Mater. Process. Technol. 173 (2006) 151-156. 
[38] K. Sodiyi, I. Sigalas, A. Guven, Y. Turan, Performance of mixed ceramics and CBN during hard turning of martensitic stainless steel, Int. J. Adv. Manuf. Technol. 77 (2015) 861-871.

[39] M.B. Da Silva, V.T.G. Naves, J.D.B. De Melo, C.L.F. De Andrade, W.L. Guesser, Analysis of wear of cemented carbide cutting tools during milling operation of gray iron and compacted graphite iron, Wear 271 (2011) 2426-2432.

[40] J. Gurland, P. Bradzil, Relation of strength, composition and grain size of sintered WC-Co, Trans. AIME 203 (1955) 311-315.
[41] E.M. Trent, P.K. Wright, Metal Cutting, 4th edition, Butterworth-Heinemann, London, UK, 2001.

[42] R.M. Genga, L.A. Cornish, M. Woydt, K. Sobiyi, C. Polese, Wear and mechanical properties of SPS and LPS WC and NbC based cemented carbide inserts, International Symposium on Wear Resistant Alloys for the Mining and Processing Industry, The Minerals, Metals and Materials Society (TMS), 2018, pp. 547-568 ISBN: 978-0-692-05382-9. 